\title{
Are the unhappy unemployed to blame for unrest? Scrutinising participation in the Arab Spring uprisings
}

\author{
${ }^{1}$ SaferClobe, Helsinki, Finland, E-mail: kari.paasonen@tuni.fi \\ ${ }^{2}$ Tampere Peace Research Institute (TAPRI), Tampere University, Tampere, Finland, E-mail: kari.paasonen@tuni.fi
}

\begin{abstract}
:
Unemployment is considered a significant driver behind the so-called Arab Spring, and more generally behind protests, rebellions, and civil wars. However, the empirical evidence of this hypothesised link between unemployment and political instability is scant and contradictory. This article contributes to filling this gap. In addition, this is the first study which will concentrate on the role of unemployment in the case of the Arab Spring uprisings. The study utilises regression analysis and several survey data sets. The results show that compared to the employed, the unemployed are not more likely to have participated in the Arab Spring unrests or protests in the Arab world in general. Further analyses reveal that, as expected, the unemployed are less satisfied with life and not particularly interested in politics. In turn, being dissatisfied with life does not influence the likelihood that an individual revolts, but those interested in politics are considerably more active protesters. Taken together, the results indicate that the Arab unemployed were unhappy, but due to their low interest in politics this dissatisfaction did not drive them to the streets. These findings together with some earlier results from different corners of the world suggest that the linkage of unemployment and political instability is remarkably weaker than often assumed.
\end{abstract}

Keywords: Arab Spring, insurgency, protest mobilisation, unemployment

DOI: 10.1515/peps-2019-0007

\section{Introduction}

In December 2010 in a Tunisian provincial town, the fruit vendor Mohamed Bouazizi set himself on fire to protest against the actions of corrupted police. This event sparked unrests which also erupted in the capital Tunis, and soon unseated president Ben Ali. Revolts inspired by the peaceful revolution in Tunisia rolled through most of the Arab world in 2011. These uprisings that came to be known as the Arab Spring toppled several rulers who had governed for decades, but they also sparked brutal civil wars. Although mostly what is considered as the Arab Spring occurred in 2011, its impact is clearly evident still today. The war in Syria has continued for more than 8 years and caused reportedly over 500,000 fatalities. There are ongoing civil wars also in Yemen and Libya, and there is much turbulence and insecurity elsewhere in the region.

Unemployment is often nominated as a driver behind these uprisings, and the Arab Spring was not the first time that unemployment has been blamed for riots in the region (Ottaway \& Hamzawy, 2011, pp. 4-6; Sadiki, 2000). Also outside the Arab world, unemployment is commonly seen as a factor which considerably increases the likelihood of various forms of political instability from protesting and rioting to terrorism and civil wars. As it is assumed that unemployment causes political instability, this is then followed by assuming that creating employment is a way to foster peace (Berman, Callen, Felter, \& Shapiro, 2011, p. 497). However, there is hardly any empirical evidence to confirm either the link between unemployment and political instability or the link between job creation and increased stability (Cramer, 2011; Holmes, McCord, Hagen-Zanker, Bergh, \& Zanker, 2013). Nor has, in the case of the Arab Spring, the role of unemployment been studied thoroughly. This study aims at filling this gap. The article will primarily focus on the specific case of the Arab Spring, but it will also analyse the relationship between unemployment and protest in the Arab countries more generally.

To understand its potential role behind the rebellions in the Arab world, a few notions about unemployment in the region are worth making. Figure 1 shows that unemployment in the Arab world is substantial compared to the world average. Notably, however, the Arab countries as a whole did not see the increase in unemployment 
after the 2008 financial crisis. Actually, in 2010, on the eve of the Arab Spring, the average of the unemployment rates of the Arab countries was at the lowest level since 1991.

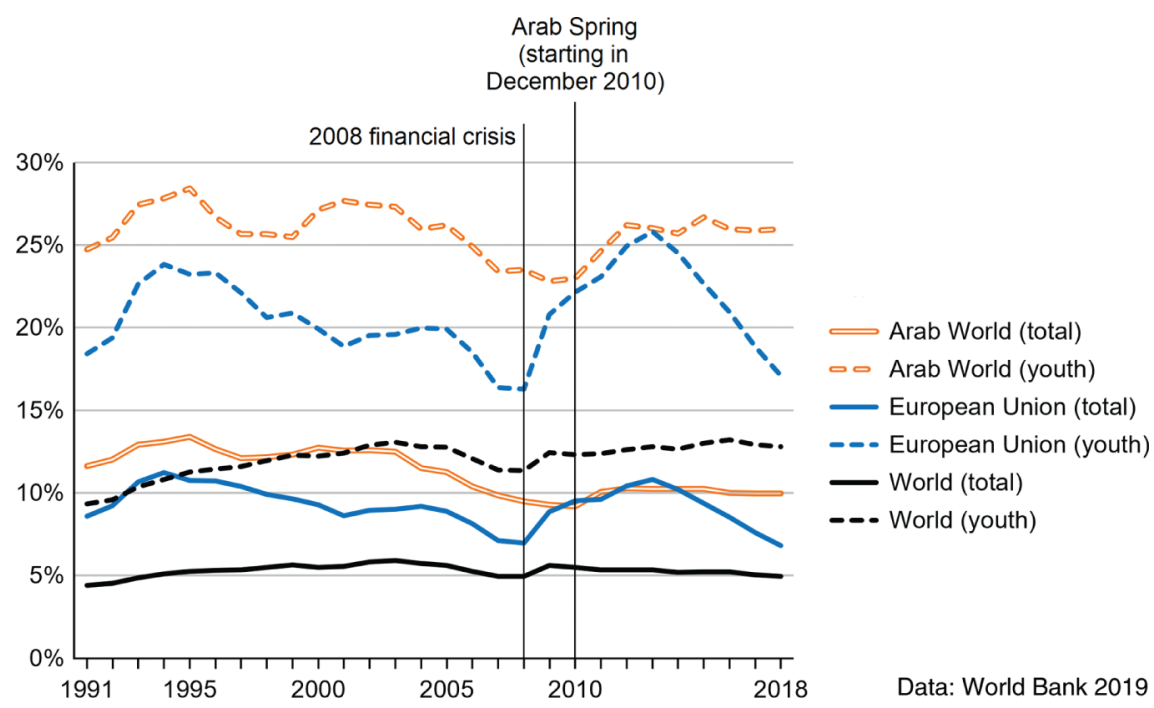

Figure 1: Unemployment rates in the Arab world, the European Union, and globally 1991-2018.

In the Arab world, three groups especially suffered from high unemployment rates: the youth, the educated and women. A higher unemployment rate among the youth is not uncommon. As Figure 1 shows, the young were unemployed more often also elsewhere. In many Arab countries, unemployment rates among the highly educated were higher compared to those with lower education levels. This, in turn, was a unique situation in the world (Chaaban, 2010, pp. 18-20; Goldstone, 2011, p. 12; Mirkin, 2013, p. 24; World Bank, 2019).

Figure 2 shows the unemployment rates in the Arab countries prior to the eruption of the Arab Spring. The unemployment rates presented in Figure 1 and Figure 2 are taken from the data collected by the International Labour Organization. This data is mainly based on labour force surveys. There are certainly some inaccuracies in it but they do not affect the overall picture of Figure 2; the Arab countries were very heterogeneous in terms of unemployment when the Arab Spring started. Where many Arab countries faced significant problems in providing employment opportunities for their citizens, there has been a lot of labour migration to oil exporting Gulf countries (Mirkin, 2013, p. 17).

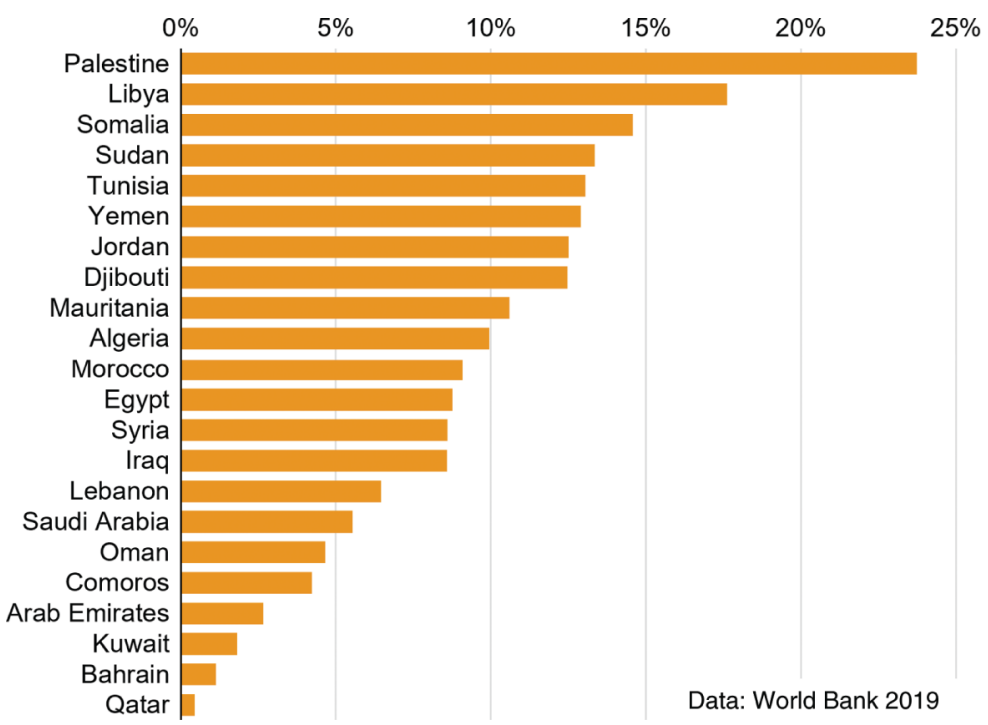

Figure 2: Unemployment rates in the Arab League member countries in 2010.

The Arab Spring has been seen as an outcome of various factors; high unemployment, a large share of the youth population, autocratic and bad governance, human right violations, increased food prices, an increase in educational attainment, social media, a state dominated economic system, and oil. Unemployment is maybe the most often mentioned of these factors (see for example Allansson, Baumann, Taub, Themnér, \& Wallensteen, 2012; Campante \& Chor, 2012; Gelvin, 2012; Goldstone, 2011; Hoffman \& Jamal, 2012; Malik \& Awadallah, 2013; Mirkin, 2013; Ottaway \& Hamzawy, 2011). 
Some have seen the relationship between unemployment and the Arab Spring clearly as causal: the International Labour Organization (2011) titled its analysis straightforwardly "Youth unemployment in the Arab world is a major cause for rebellion." Some have been more cautious in their wording. Malik and Awadallah (2013, p. 296) posed that "Arab revolutions were fueled by poverty, unemployment and lack of economic opportunity." The linkage has also been promoted in mass media, for example in an article by The Guardian (2011) "The frustrated generation at the heart of the protests tell how their progress is being stifled by unemployment and corruption."

The relationship between unemployment and the Arab Spring is seldom analysed more closely; still, some have done slightly more than just mentioned it. The results of Campante and Chor (2012) indicate that people are more willing to protest in countries with high unemployment and a rapid increase in years of schooling, and most Arab countries appeared in this group of countries. Byun and Hollander (2015) find that unemployment did not have a significant impact on the level of unrest a country faced during the Arab Spring.

Some studies have, based on different survey data sets, analysed drivers of individual level protest participation. Doherty and Schraeder (2015) study Tunisia and find that there were no statistically significant differences between the unemployed and the employed as to how often they took part in protests before the ousting of Ben Ali and in protests after elections. Shafiq and Vignoles (2015) note that "perhaps surprisingly" their descriptive data do not show that the unemployed would have been more likely to protest.

Utilising the first wave of the Arab Barometer survey, Hoffman and Jamal (2012, pp. 181-184) report that "[c]ontrary to what might be expected" - being unemployed lowers the likelihood for an individual to protest. Beissinger, Jamal, \& Mazur (2012, p. 13) as well as Hoffman and Jamal (2014, pp. 599, 603-604) have studied protest participation in Tunisia and Egypt based on the second wave of the Arab Barometer. Both studies find that unemployment was not a statistically significant predictor of participation in the Arab Spring insurgencies in either country. Taken together, this existing research provides a mixed picture about the relationship between unemployment and the Arab Spring.

This article contributes to the existing research in many ways. The above-mentioned studies have made some observations about unemployment and the Arab Spring. However, in these studies, unemployment has been one factor among others in regression analyses, or it has otherwise received minor attention. The articles that have analysed individual level participation, have mostly studied just Tunisia or Tunisia and Egypt (Beissinger et al., 2012; Doherty \& Schraeder, 2015; Hoffman \& Jamal, 2014; Shafiq \& Vignoles, 2015). In addition, earlier studies have often modelled participation in the Arab Spring based on some other protests, they have not discussed further their scattered findings about unemployment or the inspection of the participation of the unemployed has been descriptive.

Even though unemployment is a difficult concept in the developing economies, previous studies have not paid much attention to how to operationalise it. For example, Hoffman and Jamal (2012) have counted all those who have not reported being employed as unemployed. Thus, they have counted also the retired, housewives, and students as "unemployed," which is apparently an imperfect solution. Here I will put more emphasis on tackling the problem of measuring unemployment in the Arab world. I also pay special attention to the young unemployed and the educated unemployed. This has not been done previously. To my knowledge, there are no prior studies that would have analysed the relationship of the unemployed and the Arab Spring as thoroughly as I will do. Further, as will be pointed out, there is in general surprisingly little research on the relationship between unemployment and political instability. This scarcity highlights the importance of this paper as one new empirical case study about the struggles of the unemployed.

\section{Literature survey and hypotheses}

The Arab Spring manifested itself in various forms of political instability, thus it is relevant to survey the connection of unemployment both to protesting and to organised violence. There are two main theoretical approaches suggesting that unemployment increases the likelihood of political instability. The first of these two is economic and it is often traced back to Becker (1968) who studied crimes. Later Grossman (1991) and Collier and Hoeffler (1998), among others, have promoted the economic approach and applied it to conflicts. The assumption is that individuals take part in collective acts of violence because of material inducements. When options for non-violent employment are scarce, soldiering might offer people alluring opportunities to earn money. Consequently, high unemployment rates can fuel conflicts by facilitating the recruitment of rebels. Further, Lichbach (1995, p. 342) argues that the unemployed will participate also in protests more probably because they face no opportunity-costs from losing time at paid work.

The second prominent approach is relative deprivation theory which has been more in favour of social psychologists. According to Gurr (1970), an influential contributor to the theory, relative deprivation is expe- 
rienced by those whose actual circumstances and commodities do not equal what they expected to gain and what they think they are rightfully entitled to. The individual's perception of deprivation is important, people whose expectations are not met can feel themselves deprived even if an "objective" outsider would consider otherwise. The relatively deprived use political violence to struggle against their situation. Scholars of social movements have linked relative deprivation also with protesting; those relatively deprived protest to redress the deprivation they face (Klandermans, 2011, pp. 40-42).

However, various arguments challenge this assumed positive linkage between unemployment and political instability. First, stigmatisation has been considered one of the most important obstacles for the collective action of the unemployed (Perry \& Reiss, 2011, p. 32). If public opinion and elected officials consider unemployment to be a personal fault of an individual, the insurgence of the unemployed lacks legitimacy (Chabanet \& Faniel, 2011, pp. 392-393).

Second, to think that the employed are wealthy and happy and the unemployed are deprived and unhappy might be a simplistic and a Western mindset. Cramer (2011, p. 17) reminds that globally there are millions of people whose working conditions are "so dreadful that it is probably no more difficult to recruit [rebels and soldiers] among them" than among the unemployed. There are also some issues related to the concept of being unemployed. The definition of unemployment requires that an individual is looking for work. In the developing economies, people are maybe not looking for work because they consider seeking work by conventional means useless if the informal economy and self-employment offer the major employment opportunities (World Bank, 2019). In the Arab world more than $10 \%$ of the employed work in the informal sector (Chaaban, 2010, p. 18). Another issue is that in the developing countries state welfare benefits are mostly scant or non-existent so people cannot afford to be unemployed in the sense understood in the West (Cramer, 2011, p. 15).

Third, the unemployed are a socially heterogeneous group, and many of them want to get rid of being unemployed. Both these factors hinder the formation of a collective identity which is important in collective action such as protesting (Chabanet \& Faniel, 2011, p. 394; Klandermans, 2011, p. 46).

Fourth, social movements are never spontaneous events (Chabanet \& Faniel, 2011, p. 397). Although the Arab Spring revolts have been labelled spontaneous from time to time, Gelvin (2012, pp. 54-55) reminds how the April 6 Movement among other organisations was coordinating the Egyptian uprisings. The movement, for example, organised twenty-one marches to Tahrir Square because a single march could easily have been broken by the security forces.

Fifth, the unemployed lack resources such as money, political skills, leadership, organisational resources, and social networks which are necessary for mobilising a protest (Klandermans, 2011, pp. 45-46; Schlozman \& Verba, 1979, pp. 12-20).

Further, protests do not provide employment opportunities to the protesters (Klandermans, 2011, p. 55). The rational unemployed can thus be expected to devote their time and skills to finding work rather than to protesting (Schlozman \& Verba, 1979, p. 351). This so-called free rider problem is not less notable in the case of authoritarian Arab states where rioting is indeed risky.

The contention of the economic approach that money is an essential motive for an individual to join groups that use violence is also challenged. For example, people have given manifold motivations for joining the Colombian guerrilla movement FARC: the allure of military life, getting a gun, personal problems, the boredom and miseries of daily life, sexual harassment at home, the wish to get training and an education, and political ideologies (Gutierréz-Sanín, 2008, pp. 14, 17, 20-25).

Last, if insurgence is considered something people do by choice, people possibly start fighting when their basic needs are filled. This rather suggests that an improved economic situation would lead to higher levels of violence at the same time that it leads to lower levels of unemployment (Berman et al., 2011, pp. 497-498). Similarly, Klandermans (2011, p. 46) suggests that those who protest are maybe not the poor and the powerless but those who are slightly better off.

\subsection{Empirical evidence}

The relationship between unemployment and protesting has gained interest for a long time. In the early 1930s a path-breaking study of Marienthal, an Austrian village of extreme unemployment, concluded that the unemployed were passive and desperate and that particularly their political interest and activity were very low (Jahoda, Lazarsfeld, Zeisel, \& Fleck, 1933/2002). Some case studies from Germany and the United Kingdom during the 1930s extrapolated similarly and thus, for a long time scholars took for granted that unemployment leads to exclusion and apathy (Baglioni, Baumgarten, Chabanet, \& Lahusen, 2010, p. 324; Perry \& Reiss, 2011, pp. 3-6). More recently, Reiss and Perry (2011) have shown that the unemployed have still protested in various countries and with varying levels of intensity during the two last centuries. Lahusen (2013) states that protests by the unemployed in Sweden, France, and Germany illustrate that collective protest actions by the unemployed are much more common than assumed in the earlier studies. 
By contrast, Giugni (2008) and Baglioni et al. (2010) have studied the mobilisation and protests of the unemployed in different European countries and discovered that their actions are in general sporadic or even marginal, and further that participation among the unemployed is rather low compared to, for example, peace and ecology activists. Olzak, Shanahan, and McEneaney (1996) find that neither the unemployment rate nor an addition of a change in the unemployment rate had any effect on the rate of race riots in the United States from 1960 to 1993. Later Olzak and Shanahan (1996) introduce some evidence that higher unemployment rates for black people and, taken especially together with increased black migration, were connected to an increase in racial riots.

Most of the studies of protesting and unemployment concentrate on Western countries, making two studies from Nigeria interesting. Based on different data, they both observe that respondents with paying jobs are more willing to take part in violent demonstrations than the unemployed (Oyefusi, 2010; Scacco, 2007). The relationship between unemployment and peaceful protest is also negative, but statistically insignificant (Oyefusi, 2010).

To sum, despite diverse conclusions from this earlier research, there is very little evidence to show that the unemployed are active rioters. Even less have I become convinced that the unemployed would be active protesters compared to the employed. Rather the evidence seems to run in an opposite direction; although unemployment has led to unrest this happens sporadically and, generally, the protests of the unemployed appear to be rare.

The evidence is no more concordant in the case of unemployment and organised violence. Some studies indicate a positive relationship between the two, some suggest no relationship, and some studies have found, maybe most interestingly, a negative relationship: the more unemployment, the less violence.

In his review, Cramer (2011, p. 24) concluded that "There is no remotely convincing evidence at the crosscountry, large-N level, at the quantitative case study level, or at the ethnographic, 'qualitative' level, for any bold claims that unemployment is a mechanistic causal factor in violent conflicts in developing countries. The evidence on youth unemployment is even weaker."

Some case studies have found that the unemployed are eager to start rebelling. In a study, half of the interviewed al-Shabaab fighters were unemployed when they were recruited and the rest had low-income jobs (Botha \& Abdile, 2014, pp. 7-8). Similarly, among the youth of the Nigerian delta, being unemployed increased the individual's likelihood to be willing to take part in an armed struggle. But interestingly, if also adult respondents were included in the analysis, being unemployed, in turn, lowered the likelihood that a respondent wants to take up arms (Oyefusi, 2010). Based on two data sets, Gutierréz-Sanín (2008, pp. 17-18) finds that most of the FARC fighters were working before joining the group. In the other data set "not one declared" to have been unemployed. Many studies have found that unemployment has rather a slender effect. Studying young people in Afghanistan, Columbia, and Somalia, Proctor (2015) finds no relationship between their unemployment and their support for or willingness to engage in political violence. Those who travelled from Finland to conflict zones in Syria considered an anti-Muslim atmosphere the most central reason for leaving; they had had varying employment and socio-economic situations (Creutz, 2015).

As one approach is to study participation at the individual level as above, another way is to study temporal and regional relations. Berman et al. (2011) find that in Afghanistan, Iraq, and the Philippines higher unemployment rates predict a lower intensity of insurgent attacks against government forces and their allies. In the same way, in Northern Ireland, White (1993, pp. 580-582) and Thompson (1989) have both found that depending on model specifications and what exactly is measured, a higher unemployment rate either is not connected to the level of political violence or is connected to a lower level of violence. By contrast, using imputed data of Catholic and Protestant unemployment rates in Northern Ireland, Honaker (2010) finds that the level of violence targeting civilians rises as the unemployment rate rises. Studying 24 developing countries, Azeng and Yogo (2013) report that higher youth unemployment rates are connected to higher likelihood of internal conflict.

As a conclusion of the above-presented and other empirical research I have read, the diversity both in results and in methods is considerable. Further, almost all studies are case studies of one or a few countries, or in some situations collections or reviews of case studies. Often the sample sizes are relatively small. And in many cases, the findings presented are drawn from studies which do not focus on unemployment. I have found no systematic global scale study about the relationship between unemployment and protesting nor between unemployment and organised violence - compared to, for example, a study by Buhaug, Cederman, and Gleditsch (2014) of civil wars, inequalities, and ethnicity which covered all independent states of the world and a timespan from 1960 to 2005.

\subsection{Hypotheses}

All hypotheses will be studied in the context of the Arab Spring and the Arab countries. 
Hypothesis 1. The unemployed are more likely to protest than the employed.

Hypothesis 2. The young unemployed are more likely to protest than the young employed.

Hypothesis 3. The educated unemployed are more likely to protest than the educated employed.

As discussed above, relative deprivation theory and the economic approach both let us assume that the unemployed are more likely to protest. For hypothesis 2 which concerns young people, there are both state level and individual level bases. There is evidence that countries experiencing exceptionally large youth cohorts, so-called "youth bulges," have a higher risk of riots or violent demonstrations, domestic armed conflict and terrorism (Urdal, 2006). At the individual level, young age is a factor increasing significantly the likelihood to take part in a protest, both violent and peaceful (Hoffman \& Jamal, 2012, p. 184; Oyefusi, 2010, pp. 334, 337).

A higher level of education predicts a higher level of participation in various kinds of political activities, ranging from discussing politics to taking part in demonstrations (Campante \& Chor, 2012, p. 168). In hypothesis 3, as in hypothesis 2, we thus search for a joint effect, this time for unemployment and education. Following relative deprivation theory, we also expect high participation in insurgencies among the highly educated unemployed. Those who educate themselves probably have higher expectations for life. When these expectations are not met and the educated remain unemployed, we can assume that they become deprived, frustrated and eager to take to the streets.

Hypotheses 2 and 3 also have grounds related to the particular case of the Arab Spring. It has been stated that the young were "at the forefront" in the uprisings (Bjorvatn \& Høigilt, 2016) and that it was especially youth unemployment which sparked the Arab Spring (Hoffman \& Jamal, 2012, p. 168; International Labour Organization, 2011; Mirkin, 2013, p. 7). As noted above, in addition to the youth, in many Arab countries unemployment affected especially the highly educated. Campante and Chor (2012) suggested that it was specifically the combination of high unemployment and an increase in education which resulted in the onset of the Arab Spring.

Hypothesis 4. The unemployed are less satisfied with their lives than the employed.

Hypothesis 5. The unemployed are less interested in politics than the employed.

Hypothesis 6. People who are less satisfied with their lives are more likely to protest.

Hypothesis 7. People who are more interested in politics are more likely to protest.

Hypotheses 4-7 study mechanisms that determine whether the unemployed participate in the protests. Two factors are studied more closely, satisfaction with life and interest in politics. Satisfaction with life is an essential theme in relative deprivation theory. As discussed earlier, being unemployed can reduce people's interest in politics and political activity (Jahoda et al., 1933/2002). On the other hand, political skills are assumed to be a critical resource in the process of mobilisation (Klandermans, 2011, pp. 45-46; Schlozman \& Verba, 1979, pp. 12-20).

The unemployed are compared with the employed instead of comparing the unemployed to all other respondents. This is done because we expect that unemployed people would calm down if they would get jobs. Or if seen from the perspective of relative deprivation theory, the unemployed feel deprived because they compare themselves with the employed.

\section{Data, methods, and measurements}

Used data sets are the third wave of the Arab Barometer (referred to as ABIII) and the sixth wave of the World Values Survey (WVS6). In total ABIII has over 14,000 respondents from twelve different Arab countries. From WVS6, eight Arab countries and their roughly 10,000 respondents are included. Later, when I refer to "all countries" of WVS6, this always stands for all these eight analysed Arab countries of WVS6. Following the most common definition, I consider the member states of the Arab League to be Arab countries. The data sets represent adults 18 years old and older in each country. Table 1 presents the countries included in the analyses and those Arab countries of WVS6 which are excluded because some questions were not asked. The table also shows when the interviews have been conducted in these countries.

The article mainly studies all Arab countries in which there is data as one sample. To supplement the picture of the mobilisation of the unemployed, hypothesis 1 is also studied in some individual countries and country groups. There could be country-specific differences in the participation of the unemployed because, for example, labour unions play a role in protest mobilisation and they have different relationships to the unemployed in different countries (Chabanet \& Faniel, 2011, pp. 398-404). It is also suggested that in different Arab Spring 
countries different socio-economic groups mobilised the rebellions (Anderson, 2011, p. 2). Because the article has a special focus on the Arab Spring, the individually studied countries are Egypt, Libya, Tunisia, and Yemen. According to Allansson et al. (2012), p. 46 these countries were hardest hit by the uprisings together with Bahrain and Syria, from the two last-mentioned countries there is no data.

Table 1: Included and excluded countries in the analyses and field periods in each country.

\begin{tabular}{llrlr}
\hline & ABIII data & & WVS6 data & \\
\hline Algeria & Included & $3 / 2013-4 / 2013$ & Included & $1 / 2014-10 / 2014$ \\
Egypt & Included & $3 / 2013-4 / 2013$ & Excluded & $11 / 2013-12 / 2013$ \\
Iraq & Included & $6 / 2013$ & Included & $2 / 2014-3 / 2014$ \\
Jordan & Included & $12 / 2012-1 / 2013$ & Included & \\
Kuwait & Included & $2 / 2014-3 / 2014$ & Excluded & $11 / 2013$ \\
Lebanon & Included & $6 / 2013$ & Included & $1 / 2014-2 / 2014$ \\
Libya & Included & $3 / 2013-4 / 2013$ & Included & $5 / 2011-6 / 2011$ \\
Morocco & Included & $4 / 2013-6 / 2013$, & Included & \\
& & $3 / 2014$ & & \\
Palestine & Included & $12 / 2012$ & Excluded & \\
Qatar & No data & & Excluded & $11 / 2013-12 / 2013$ \\
Sudan & Included & $4 / 2013-5 / 2013$ & No data & $2 / 2014$ \\
Tunisia & Included & $2 / 2013$ & Included \\
Yemen & Included & $11 / 2013-12 / 2013$ & Included \\
\hline
\end{tabular}

Linear regression - and more precisely linear ordinary least squares regression - is used with hypotheses 4 and 5. In other cases, binary logistic regression is applied. Some assumptions related to the use of regression are worth discussing here. The independence of observations is an assumption in all regression analysis. It should not cause concern in this study as the observations here are single respondents interviewed separately. A source of debate is the use of Likert scale variables in a linear regression model. In all my linear regression models the explained variable is a Likert scaled question or a combination of two Likert scaled questions. Following Vehkalahti (2008, p. 37) and Newsom (2013, p. 2) I consider that the use of Likert scale variables is justified here.

Lumley, Diehr, Emerson, and Chen (2002) argue that it "is widely but incorrectly believed" that linear regression would be valid only with normally distributed explained variables. Some previous studies have found that the normality condition loses its significance with sample sizes of some 100 observations, and Lumley et al. conclude that 500 is enough even with an extremely non-normal data. Here all explained variables of linear regression models are not normally distributed. However, the sample sizes are above 9,000, so this should not be a problem.

To tackle the challenge of measuring unemployment in developing economies I will use three ways to operationalise unemployment. First, I will simply utilise questions in which the respondents themselves report their employment status (q1005 and q1006 in ABIII, V229 in WVS6). The options given differ slightly between ABIII and WVS6, but both surveys offer options of being "unemployed" and working "full-time," i.e. 30 hours a week or more. Those respondents who answer that they are unemployed will obviously form the group under scrutiny, the unemployed. In my analyses, those who work full-time constitute the group of employed. Respondents can also have chosen to be part-time employed, self-employed, retired, housewife, and student. All these respondents who are neither full-time workers nor unemployed will be grouped as having other employment status. Part-time workers are classified as having other employment status because it is unknown whether they work one hour or 29 hours a week. Categorising them as employed or unemployed would, either way, disturb the analysis. This division of respondents into three groups is coded by two separate binary variables. In the "Employed" variable the employed are coded as 1 and all the rest of the respondents as 0. In the "Others" variable respondents with other employment status are coded as 1 and unemployed and employed respondents as 0 .

Because the unemployed are coded as 0 in both variables, they form the reference category. Consequently, the "Employed" variable will enable us to compare the employed with the unemployed (Long, Long, \& Freese, 2006, pp. 417-418). We are not interested in comparing the unemployed and the "Others" group because the "Others" group is so heterogeneous. It would have been possible to exclude respondents with any other employment status than employed or unemployed but including "Others" increases the sample size. Bigger sample size in turn means that the control variables are better adjusted.

As argued earlier, the nature of labour markets in the Arab world challenges the definition of being unemployed. Robbins, project director of the Arab Barometer, assumes that some respondents who are not currently working might still have answered that they work when they mean that they work in general. This can particularly be the case with those working in the informal sector (Robbins, 2014). Thus, there can be some bias in this 
measure of unemployment as the responses to this question may not fully reflect the formal definition of unemployment. To handle these issues, I also use income as a proxy for employment. Since most people arguably get most of their money from work it is reasonable to assume that people who are mostly unemployed have a low income.

I use two ways to measure income which I call absolute income and relative income. These are the two other operationalisations of unemployment. In WVS6, respondents are asked (v239) to specify themselves in which of the ten shown income group they belong. In ABIII I have calculated the income groups myself based on the monthly income of the respondents (q1014). I have divided all respondents in each country into ten groups so that the groups are as equal in size as possible. The respondents of both ABIII and WVS6 are coded so that those in group 1 have the lowest income and those in group 10 the highest income within a country. For various reasons, these questions about absolute income do not necessarily tell whether the respondents' income covers their needs; for example, there are differences in price levels within countries. In ABIII the relative income is based on question (q1016) where respondents are asked about the sufficiency of their household income. Those facing significant difficulties in meeting their needs are coded as 1 and at the opposite end respondents able to save as 4. In WVS6 there is no question to measure relative income. In analyses of relative and absolute income only those respondents are included who have to the employment status question answered that they are unemployed, part-time employed, full-time employed, or self-employed.

In ABIII, respondents are asked (q800a) whether they in 2011 and 2012 had participated in demonstrations and rallies to which the Arab Spring led. Following from this wording in ABIII the article concentrates in the Arab Spring related protests in years 2011 and 2012. WVS6 provides information on whether respondents have during the last year attended peaceful demonstrations (v87 and v92). This is coded as a binary variable where 1 is for respondents who did protest during the last year and 0 for those who did not.

The best question to measure satisfaction in life in ABIII is (q102a) "Generally speaking, how would you compare your living conditions with the rest of your fellow citizens?" The five options given are coded from 1, "much worse," to 5, "much better." WVS6, instead, provides question (v23) asking "All things considered, how satisfied are you with your life as a whole these days?." The scale for answers ranges from 1, "completely dissatisfied," to 10, "completely satisfied." The relative deprivation theory assumes that people who feel deprived after comparing themselves to some other people are dissatisfied and start rebelling. Thus, questions both from ABIII and WVS6 measure whether the respondent is relatively deprived in the sense of the theory.

There are two four-step questions both in ABIII (q404 and q405) and in WVS6 (v7 and v84) where respondents rate their interest in politics. For both data sets, I have calculated the average of the two items. The scale goes from 1.0 to 4.0: the more interest in politics the respondent has, the higher the value.

The control variables in each model are age, education level, gender, country of residence, and whether the respondent lives in an urban or rural area. For binary logistic regression, education (question q1003 in ABIII, v248 in WVS6) is coded on a four-step scale where 1 implies the lowest educational level and 4 the highest. The "Age" variable equals simply the age of the respondent in years. Gender is coded as 1 for males and 0 for females. In most countries of ABIII, the respondents are coded as urban, 1, or rural, 0 , based on question (q13) which specifically asks this. For respondents from Kuwait this information is not available but $100.0 \%$ of Kuwaitis live in urban areas (World Bank, 2019), so I have coded all Kuwaiti respondents as urban. In Palestine "refugee camp" is available as a third option, Palestinians living in refugee camps are excluded from analyses. In WVS6 respondents living in towns with a population greater than 10,000 are considered urban and respondents living in towns smaller than that, rural (v253). Country is used as a control variable when more than one country is included in the sample. There is a separate binary variable for each country except for the country serving as reference category. Even though these binary country variables are not reported in the tables, the country variables are included in all analyses that study more than one country. In hypotheses 4 and 5 the results are controlled for marital status (q1010, v57), those married are coded as 1 and all others as 0.

Descriptive statistcs, frequency tables and correlation matrices of the studied variables can be found as appendices.

When respondents are asked about protesting and interests in politics, they might try to avoid answering or answer dishonestly. This is a possible source of error. ABIII includes question (q513) asking how satisfied respondents are with their government. If respondents would have been afraid of consequences, one could expect good grades for governments in this question. However, on a scale from 0 to 10 , the most common answer has been zero: the respondent is absolutely unsatisfied with the government. About half, $52.1 \%$, of the respondents have evaluated their satisfaction to be lower than five, which is the median, and $29.1 \%$ have considered themselves more satisfied than five. In addition, in this question the share of missing answers, $3.6 \%$, is relatively low and close to the share of missing answers for example in question (q701a) concerning trade with other countries, there $4.0 \%$ have failed to answer. The question about foreign trade could have had less missing answers if many respondents had refused to answer in fear of state surveillance. These figures do not support 
suspicions of unwillingness to answer truthfully in fear of consequences. Last, there is no apparent reason why this potential source of error would affect the unemployed and the employed differently.

\section{Results}

Figure 3 shows that, maybe not surprisingly, students were most active in the Arab Spring uprisings, the retired and the housewives the most passive. Therefore, it appears that employment status is linked to the likelihood of protest participation. However, the difference between the unemployed and the employed seems marginal.

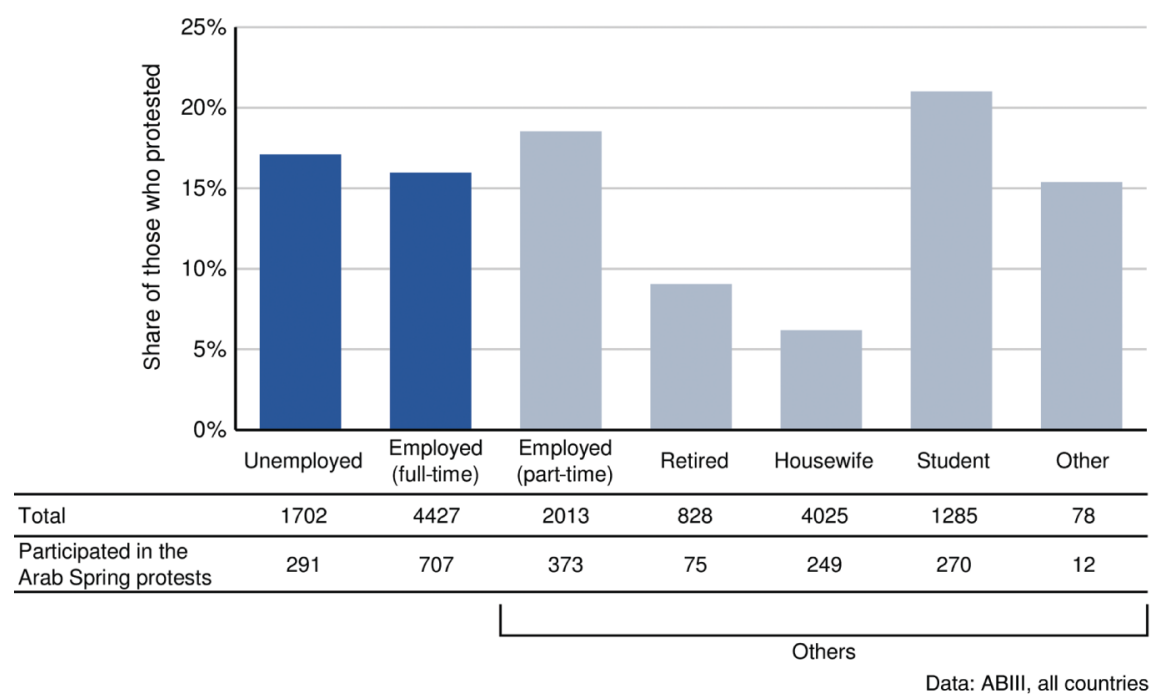

Figure 3: Protest participation by employment status.

Table 2: Binary logistic regression, hypothesis 1: protest participation of the unemployed. ${ }^{a}$

\begin{tabular}{|c|c|c|c|c|c|}
\hline $\begin{array}{l}\text { Explained variable } \\
\text { Data set } \\
\text { Sample }\end{array}$ & $\begin{array}{r}\text { Protesting } \\
\text { ABIII } \\
\text { All } \\
\text { countries }\end{array}$ & $\begin{array}{r}\text { Protesting } \\
\text { WVS6 } \\
\text { All } \\
\text { countries }\end{array}$ & $\begin{array}{r}\text { Protesting } \\
\text { ABIII } \\
\text { All } \\
\text { countries }\end{array}$ & $\begin{array}{r}\text { Protesting } \\
\text { WVS6 } \\
\text { All } \\
\text { countries }\end{array}$ & $\begin{array}{r}\text { Protesting } \\
\text { ABIII } \\
\text { All } \\
\text { countries }\end{array}$ \\
\hline Urban residence & $\begin{array}{r}0.231^{* * *} \\
(0.063)\end{array}$ & $\begin{array}{r}0.237^{* * *} \\
(0.070)\end{array}$ & $\begin{array}{c}0.185^{*} \\
(0.087)\end{array}$ & $\begin{array}{r}0.254^{* * *} \\
(0.085)\end{array}$ & $\begin{array}{r}0.222^{* * *} \\
(0.076)\end{array}$ \\
\hline Male & $\begin{array}{r}0.883^{* * * *} \\
(0.059)\end{array}$ & $\begin{array}{r}0.872^{* * *} \\
(0.066)\end{array}$ & $\begin{array}{r}0.628^{* * * *} \\
(0.094)\end{array}$ & $\begin{array}{r}0.648^{* * *} \\
(0.089)\end{array}$ & $\begin{array}{r}0.719^{* * * *} \\
(0.079)\end{array}$ \\
\hline Age & $\begin{array}{r}-0.015^{* * *} \\
(0.002)\end{array}$ & $\begin{array}{r}-0.008^{* * *} \\
(0.002)\end{array}$ & $\begin{array}{r}-0.012^{* * * *} \\
(0.004)\end{array}$ & $\begin{array}{r}-0.009^{* *} \\
(0.003)\end{array}$ & $\begin{array}{r}-0.013^{* * * *} \\
(0.003)\end{array}$ \\
\hline High education & $\begin{array}{r}0.315^{* * *} \\
(0.029)\end{array}$ & $\begin{array}{r}0.337^{* * *} \\
(0.037)\end{array}$ & $\begin{array}{r}0.309^{* * *} \\
(0.040)\end{array}$ & $\begin{array}{r}0.278^{* * *} \\
(0.046)\end{array}$ & $\begin{array}{r}0.266^{* * *} \\
(0.035)\end{array}$ \\
\hline \multicolumn{6}{|c|}{ Employment status (unemployed as reference category) } \\
\hline $\begin{array}{l}\text { Employed } \\
\text { Others }\end{array}$ & $\begin{array}{r}-0.062 \\
(0.089) \\
-0.283^{* * *} \\
(0.084)\end{array}$ & $\begin{array}{r}-0.179 \\
(0.112) \\
-0.389^{* * *} \\
(0.103)\end{array}$ & & & \\
\hline High income (absolute) & & & $\begin{array}{r}0.015 \\
(0.014)\end{array}$ & $\begin{array}{r}0.034 \\
(0.019)\end{array}$ & \\
\hline High income (relative) & & & & & $\begin{array}{r}0.018 \\
(0.036)\end{array}$ \\
\hline Constant & $\begin{array}{r}-0.830^{* * *} \\
(0.139)\end{array}$ & $\begin{array}{r}-2.332^{* * *} \\
(0.191)\end{array}$ & $\begin{array}{r}-0.858^{* * *} \\
(0.204)\end{array}$ & $\begin{array}{r}-2.081^{* * *} \\
(0.234)\end{array}$ & $\begin{array}{r}-0.782^{* * *} \\
(0.190)\end{array}$ \\
\hline $\mathrm{N}$ & 14,173 & 9,331 & 6,011 & 5,149 & 7,844 \\
\hline $\mathrm{R}^{2}$ & 0.136 & 0.099 & 0.141 & 0.078 & 0.134 \\
\hline
\end{tabular}

${ }^{a}$ In Table 2, as in each table reporting results of binary logistic regression, the Cox and Snell $\mathrm{r}^{2}$ is reported.

Models controlled for country (not reported). ${ }^{*} p<0.05,{ }^{* *} p<0.01,{ }^{* * *} p<0.005$. Standard errors in parentheses. 
In the two leftmost analyses of Table 2, which utilise the employment status question, the results of the hypothesis can be read from the "Employed" variable. According to both data sets the employed were slightly less active protesters than the unemployed, however, these differences are not statistically significant. This model can be considered as the base model which will be modified when studying hypotheses 2 and 3 . The three rightmost analyses show the alternative measurements for unemployment, absolute and relative income. Here the coefficients suggest that the higher the income, the higher the likelihood of an individual to take part in protests. In the case of absolute income and WVS6 this relationship comes close to statistical significance $(p=$ 0.071). Although the results in hypothesis 1 differ to some extent depending on which of the three measurements of unemployment is used, the central finding is obvious. None of these analyses provides appreciable support for the hypothesis that the unemployed would be more active protesters than the employed. Because there are no great differences between the three operationalisations, the direct question of employment status will be the only measure of unemployment used from now on.

Table 3 shows the results of the leftmost model of Table 2 in the subsamples of some countries and country groups. When Egypt, Libya, Tunisia, and Yemen are studied together, the employed are statistically significantly more active in protesting than the unemployed. However, in the subsample of "other countries," which includes all countries except the four countries studied separately, the employed protest statistically significantly less probably than the unemployed. If all these countries of the ABIII data were studied one by one, it would turn out that the coefficients of five countries support the hypothesis, two of these countries suggesting a statistically significant relationship, and seven countries contradict our assumption, one of these seven, Libya, being statistically significant. The coefficients show that in some countries the difference between the unemployed and the employed is notable, whereas in some countries, as in Tunisia, there are practically no differences between these groups. Taken together, no unambiguous relationship appears between protest participation and being unemployed.

Table 3: Binary logistic regression, hypothesis 1: protest participation of the unemployed by country.

\begin{tabular}{|c|c|c|c|c|c|c|}
\hline $\begin{array}{l}\text { Explained variable } \\
\text { Data set } \\
\text { Sample }\end{array}$ & $\begin{array}{r}\text { Protesting } \\
\text { ABIII } \\
\text { Egypt }\end{array}$ & $\begin{array}{r}\text { Protesting } \\
\text { ABIII } \\
\text { Libya }\end{array}$ & $\begin{array}{r}\text { Protesting } \\
\text { ABIII } \\
\text { Tunisia }\end{array}$ & $\begin{array}{r}\text { Protesting } \\
\text { ABIII } \\
\text { Yemen }\end{array}$ & $\begin{array}{r}\text { Protesting } \\
\text { ABIII } \\
\text { Egypt, Libya, Tunisia, } \\
\text { and Yemen }\end{array}$ & $\begin{array}{r}\text { Protesting } \\
\text { ABIII } \\
\text { Other } \\
\text { countries }\end{array}$ \\
\hline Urban residence & $\begin{array}{r}0.753^{* * *} \\
(0.187)\end{array}$ & $\begin{array}{c}0.412^{*} \\
(0.195)\end{array}$ & $\begin{array}{c}0.441^{*} \\
(0.184)\end{array}$ & $\begin{array}{c}0.289^{*} \\
(0.135)\end{array}$ & $\begin{array}{r}0.455^{* * *} \\
(0.084)\end{array}$ & $\begin{array}{l}-0.081 \\
(0.095)\end{array}$ \\
\hline Male & $\begin{array}{r}1.214^{* * *} \\
(0.228)\end{array}$ & $\begin{array}{r}1.640^{* * * *} \\
(0.147)\end{array}$ & $\begin{array}{r}1.556^{* * *} \\
(0.196)\end{array}$ & $\begin{array}{c}0.300^{*} \\
(0.141)\end{array}$ & $\begin{array}{r}1.090^{* * *} \\
(0.081)\end{array}$ & $\begin{array}{r}0.626^{* * *} \\
(0.086)\end{array}$ \\
\hline Age & $\begin{array}{l}-0.013 \\
(0.008)\end{array}$ & $\begin{array}{l}-0.006 \\
(0.005)\end{array}$ & $\begin{array}{r}-0.034^{* * *} \\
(0.006)\end{array}$ & $\begin{array}{l}-0.009 \\
(0.005)\end{array}$ & $\begin{array}{r}-0.016^{* * *} \\
(0.003)\end{array}$ & $\begin{array}{r}-0.012^{* * *} \\
(0.003)\end{array}$ \\
\hline High education & $\begin{array}{r}0.637^{* * *} \\
(0.106)\end{array}$ & $\begin{array}{r}0.229^{* * *} \\
(0.080)\end{array}$ & $\begin{array}{r}0.513^{* * *} \\
(0.097)\end{array}$ & $\begin{array}{r}0.314^{* * *} \\
(0.063)\end{array}$ & $\begin{array}{r}0.349^{* * *} \\
(0.039)\end{array}$ & $\begin{array}{r}0.288^{* * *} \\
(0.047)\end{array}$ \\
\hline \multicolumn{7}{|c|}{ Employment status (unemployed as reference category) } \\
\hline Employed & $\begin{array}{r}0.336 \\
(0.356)\end{array}$ & $\begin{array}{r}0.898^{* * *} \\
(0.291)\end{array}$ & $\begin{array}{r}0.008 \\
(0.229)\end{array}$ & $\begin{array}{r}0.056 \\
(0.242)\end{array}$ & $\begin{array}{c}0.259^{*} \\
(0.129)\end{array}$ & $\begin{array}{r}-0.331^{* *} \\
(0.127)\end{array}$ \\
\hline Others & $\begin{array}{r}0.085 \\
(0.373)\end{array}$ & $\begin{array}{c}0.579^{*} \\
(0.272)\end{array}$ & $\begin{array}{r}0.024 \\
(0.221)\end{array}$ & $\begin{array}{l}-0.429 \\
(0.220)\end{array}$ & $\begin{array}{l}-0.025 \\
(0.122)\end{array}$ & $\begin{array}{r}-0.488^{* * *} \\
(0.116)\end{array}$ \\
\hline Constant & $\begin{array}{r}-4.747^{* * *} \\
(0.587)\end{array}$ & $\begin{array}{r}-3.147^{* * *} \\
(0.508)\end{array}$ & $\begin{array}{r}-2.738^{* * * *} \\
(0.425)\end{array}$ & $\begin{array}{c}-0.658^{*} \\
(0.335)\end{array}$ & $\begin{array}{r}-1.315^{* * *} \\
(0.193)\end{array}$ & $\begin{array}{r}-2.025^{* * *} \\
(0.191)\end{array}$ \\
\hline $\mathrm{N}$ & 1,186 & 1,160 & 1,195 & 1,116 & 4,657 & 9,516 \\
\hline $\mathrm{R}^{2}$ & 0.122 & 0.154 & 0.153 & 0.084 & 0.166 & 0.040 \\
\hline
\end{tabular}

Models analysing more than one country controlled for country (not reported). ${ }^{*} p<0.05,{ }^{* *} p<0.01,{ }^{* * *} p<0.005$. Standard errors in parentheses.

To study hypothesis 2, I have run the base model of hypothesis 1 but included only respondents 18-35 years old. Youth is defined following Bjorvatn and Høigilt (2016, p. 54), who argue that 35 years is an appropriate upper limit for youth in the context of the Arab world. When studying hypothesis 3, I have run the model only for respondents with higher than secondary education.

Table 4 shows that there is faintly more support among the Arab youth for hypothesis 2 than there is among the all age population for hypothesis 1 . Both data sets give a negative coefficient for the "Employed" variable, as expected based on our hypotheses, and both results come closer to being statistically significant $(p=0.077$, $p=0.094)$. In turn, there is no considerable evidence that the educated unemployed would be more active insurgents than the educated employed. 
Table 4: Binary logistic regression, hypotheses 2 and 3: protest participation of the unemployed among the youth and among the educated.

\begin{tabular}{|c|c|c|c|c|}
\hline $\begin{array}{l}\text { Explained variable } \\
\text { Data set } \\
\text { Sample }\end{array}$ & $\begin{array}{r}\text { Protesting } \\
\text { ABIII } \\
\text { All countries, only } \\
\text { youth }\end{array}$ & $\begin{array}{r}\text { Protesting } \\
\text { WVS6 } \\
\text { All countries, only } \\
\text { youth }\end{array}$ & $\begin{array}{r}\text { Protesting } \\
\text { ABIII } \\
\text { All countries, only } \\
\text { educated }\end{array}$ & $\begin{array}{r}\text { Protesting } \\
\text { WVS6 } \\
\text { All countries, only } \\
\text { educated }\end{array}$ \\
\hline Urban residence & $\begin{array}{l}0.182^{*} \\
(0.082)\end{array}$ & $\begin{array}{r}0.282^{* * *} \\
(0.094)\end{array}$ & $\begin{array}{r}0.139 \\
(0.106)\end{array}$ & $\begin{array}{r}0.245 \\
(0.127)\end{array}$ \\
\hline Male & $\begin{array}{r}0.927^{* * *} \\
(0.078)\end{array}$ & $\begin{array}{r}0.900^{* * *} \\
(0.088)\end{array}$ & $\begin{array}{r}1.207^{* * *} \\
(0.101)\end{array}$ & $\begin{array}{r}0.864^{* * *} \\
(0.121)\end{array}$ \\
\hline Age & $\begin{array}{r}-0.016^{*} \\
(0.008)\end{array}$ & $\begin{array}{r}-0.017^{*} \\
(0.009)\end{array}$ & $\begin{array}{r}-0.010^{*} \\
(0.004)\end{array}$ & $\begin{array}{l}-0.008 \\
(0.005)\end{array}$ \\
\hline High education & $\begin{array}{r}0.325^{* * *} \\
(0.042)\end{array}$ & $\begin{array}{r}0.330^{* * *} \\
(0.053)\end{array}$ & & \\
\hline \multicolumn{5}{|c|}{ Employment status (unemployed as reference category) } \\
\hline Employed & $\begin{array}{r}-0.198 \\
(0.112)\end{array}$ & $\begin{array}{r}-0.233 \\
(0.140)\end{array}$ & $\begin{array}{r}0.052 \\
(0.163)\end{array}$ & $\begin{array}{l}-0.182 \\
(0.207)\end{array}$ \\
\hline Others & $\begin{array}{r}-0.270^{* *} \\
(0.098)\end{array}$ & $\begin{array}{r}-0.436^{* * *} \\
(0.121)\end{array}$ & $\begin{array}{l}-0.061 \\
(0.163)\end{array}$ & $\begin{array}{l}-0.349 \\
(0.197)\end{array}$ \\
\hline Constant & $\begin{array}{r}-0.844^{* * *} \\
(0.243)\end{array}$ & $\begin{array}{r}-2.045^{* * *} \\
(0.313)\end{array}$ & $\begin{array}{l}-0.051 \\
(0.243)\end{array}$ & $\begin{array}{l}-0.452 \\
(0.295)\end{array}$ \\
\hline $\mathrm{N}$ & 7,072 & 4,707 & 3,984 & 2,123 \\
\hline $\mathrm{R}^{2}$ & 0.150 & 0.101 & 0.176 & 0.122 \\
\hline
\end{tabular}

Models controlled for country (not reported). ${ }^{*} p<0.05,{ }^{* *} p<0.01,{ }^{* * *} p<0.005$. Standard errors in parentheses.

The results in Table 5 substantiate hypothesis 4, the unemployed are indeed statistically significantly less satisfied. Compared to the unemployed, the employed are 0.2 or 0.8 units more satisfied on a scale of $1-5$ of the ABIII or 1-10 of the WVS6, respectively. The coefficients suggest that the unemployed are less interested in politics than the employed, as assumed in hypothesis 5, but the difference between the groups is small. Neither is the difference statistically significant, although with WVS6 it comes close to statistical significance $(p=0.059)$.

Table 5: Linear regression, hypotheses 4 and 5: satisfaction with life and interest in politics of the unemployed. ${ }^{a}$

\begin{tabular}{|c|c|c|c|c|}
\hline $\begin{array}{l}\text { Data set } \\
\text { Sample }\end{array}$ & $\begin{array}{r}\text { Satisfaction with } \\
\text { life } \\
\text { ABIII } \\
\text { All countries }\end{array}$ & $\begin{array}{r}\text { Satisfaction with } \\
\text { life } \\
\text { WVS6 } \\
\text { All countries }\end{array}$ & $\begin{array}{r}\text { ABIII } \\
\text { All countries }\end{array}$ & $\begin{array}{r}\text { WVS6 } \\
\text { All countries }\end{array}$ \\
\hline Urban residence & $\begin{array}{r}0.067^{* * *} \\
(0.015)\end{array}$ & $\begin{array}{r}0.010 \\
(0.054)\end{array}$ & $\begin{array}{r}0.017 \\
(0.016)\end{array}$ & $\begin{array}{r}-0.041^{*} \\
(0.020)\end{array}$ \\
\hline Male & $\begin{array}{r}-0.046^{* * *} \\
(0.014)\end{array}$ & $\begin{array}{r}-0.264^{* * *} \\
(0.050)\end{array}$ & $\begin{array}{r}0.193^{* * *} \\
(0.015)\end{array}$ & $\begin{array}{r}0.124^{* * *} \\
(0.019)\end{array}$ \\
\hline Age & $\begin{array}{l}-0.001 \\
(0.001)\end{array}$ & $\begin{array}{r}-0.006^{* *} \\
(0.002)\end{array}$ & $\begin{array}{r}0.007^{* * *} \\
(0.001)\end{array}$ & $\begin{array}{r}0.006^{* * *} \\
(0.001)\end{array}$ \\
\hline Married & $\begin{array}{r}0.023 \\
(0.016)\end{array}$ & $\begin{array}{r}0.251^{* * *} \\
(0.057)\end{array}$ & $\begin{array}{r}0.091^{* * *} \\
(0.017)\end{array}$ & $\begin{array}{r}0.090^{* * *} \\
(0.022)\end{array}$ \\
\hline High education & $\begin{array}{r}0.100^{* * *} \\
(0.007)\end{array}$ & $\begin{array}{r}0.213^{* * *} \\
(0.029)\end{array}$ & $\begin{array}{r}0.186^{* * * *} \\
(0.008)\end{array}$ & $\begin{array}{r}0.142^{* * *} \\
(0.011)\end{array}$ \\
\hline \multicolumn{5}{|c|}{ Employment status (unemployed as reference category) } \\
\hline Employed & $\begin{array}{r}0.215^{* * *} \\
(0.024)\end{array}$ & $\begin{array}{r}0.727^{* * *} \\
(0.101)\end{array}$ & $\begin{array}{r}0.032 \\
(0.026)\end{array}$ & $\begin{array}{r}0.072 \\
(0.038)\end{array}$ \\
\hline Others & $\begin{array}{r}0.135^{* * *} \\
(0.022)\end{array}$ & $\begin{array}{r}0.855^{* * *} \\
(0.091)\end{array}$ & $\begin{array}{r}-0.120^{* * *} \\
(0.024)\end{array}$ & $\begin{array}{r}0.031 \\
(0.035)\end{array}$ \\
\hline Constant & $\begin{array}{r}2.462^{* * *} \\
(0.041)\end{array}$ & $\begin{array}{r}4.591^{* * *} \\
(0.153)\end{array}$ & $\begin{array}{r}1.770^{* * *} \\
(0.044)\end{array}$ & $\begin{array}{r}1.547^{* * * *} \\
(0.058)\end{array}$ \\
\hline $\mathrm{N}$ & 14,379 & 9,929 & 14,397 & 9,523 \\
\hline $\mathrm{R}^{2}$ & 0.041 & 0.072 & 0.156 & 0.124 \\
\hline
\end{tabular}

aThe coefficients reported in Table 5 are unstandardized, and the coefficients of determination are adjusted.

Models controlled for country (not reported). ${ }^{*} p<0.05,{ }^{* *} p<0.01,{ }^{* * *} p<0.005$. Standard errors in parentheses.

Standard errors in parentheses.

Table 6 shows that, unlike what is assumed in hypothesis 6 , satisfaction with life does not have an effect on the likelihood of protest participation. By contrast, hypothesis 7 gets robust backing, those interested in politics 
are clearly more likely to protest. Further analyses in the two leftmost columns suggest that the slim interest in politics of the unemployed is a factor lowering their participation in protests. In other words, when interest in politics is added into the base model, being unemployed becomes a slightly stronger predictor of participation in a protest. The changes are minor, but the same shift can be observed also when adding interest in politics to the subsamples of Table 3; the coefficients of the Employed-variable move in the negative direction, and in case the coefficients are negative their $p$-values decrease and in case the coefficients are positive they turn negative or their $p$-values increase.

Table 6: Binary logistic regression, hypotheses 6 and 7: protest participation of the dissatisfied and the politically aware.

\begin{tabular}{|c|c|c|c|c|c|c|}
\hline $\begin{array}{l}\text { Explained } \\
\text { variable } \\
\text { Data set } \\
\text { Sample }\end{array}$ & $\begin{array}{r}\text { Protesting } \\
\text { ABIII } \\
\text { All countries }\end{array}$ & $\begin{array}{r}\text { WVS6 } \\
\text { All countries }\end{array}$ & $\begin{array}{r}\text { ABIII } \\
\text { All countries }\end{array}$ & $\begin{array}{r}\text { Protesting } \\
\text { WVS6 } \\
\text { All countries }\end{array}$ & $\begin{array}{r}\text { Protesting } \\
\text { ABIII } \\
\text { All countries }\end{array}$ & $\begin{array}{r}\text { Protesting } \\
\text { WVS6 } \\
\text { All countries }\end{array}$ \\
\hline \multirow{2}{*}{$\begin{array}{l}\text { Urban } \\
\text { residence }\end{array}$} & $0.233^{* * *}$ & $0.241^{* * *}$ & $0.254^{* * *}$ & $0.223^{* * *}$ & $0.248^{* * *}$ & $0.227^{* * *}$ \\
\hline & $(0.063)$ & $(0.070)$ & $(0.064)$ & $(0.071)$ & $(0.064)$ & $(0.072)$ \\
\hline Male & $\begin{array}{r}0.964^{* * *} \\
(0.057)\end{array}$ & $\begin{array}{r}0.916^{* * *} \\
(0.065)\end{array}$ & $\begin{array}{r}0.882^{* * *} \\
(0.058)\end{array}$ & $\begin{array}{r}0.934^{* * *} \\
(0.067)\end{array}$ & $\begin{array}{r}0.835^{* * *} \\
(0.060)\end{array}$ & $\begin{array}{r}0.883^{* * *} \\
(0.068)\end{array}$ \\
\hline Age & $\begin{array}{r}-0.015^{* * *} \\
(0.002)\end{array}$ & $\begin{array}{r}-0.009^{* * * *} \\
(0.002)\end{array}$ & $\begin{array}{r}-0.021^{* * *} \\
(0.002)\end{array}$ & $\begin{array}{r}-0.013^{* * *} \\
(0.003)\end{array}$ & $\begin{array}{r}-0.020^{* * * *} \\
(0.002)\end{array}$ & $\begin{array}{r}-0.013^{* * * *} \\
(0.003)\end{array}$ \\
\hline $\begin{array}{l}\text { High } \\
\text { education }\end{array}$ & $0.325^{* * *}$ & $0.362^{* * *}$ & $0.232^{* * *}$ & $0.301^{* * *}$ & $0.230^{* * *}$ & $\begin{array}{r}0.288^{* * *} \\
(0.038)\end{array}$ \\
\hline \multicolumn{7}{|c|}{ Employment status (unemployed as reference category) } \\
\hline Employed & & & & & $\begin{array}{l}-0.097 \\
(0.091)\end{array}$ & $\begin{array}{l}-0.207 \\
(0.116)\end{array}$ \\
\hline Others & & & & & $\begin{array}{r}-0.230^{* *} \\
(0.086)\end{array}$ & $\begin{array}{r}-0.410^{* * * *} \\
(0.106)\end{array}$ \\
\hline $\begin{array}{l}\text { Satisfaction } \\
\text { with life }\end{array}$ & $\begin{array}{r}0.006 \\
(0.033)\end{array}$ & $\begin{array}{l}-0.001 \\
(0.013)\end{array}$ & & & & \\
\hline $\begin{array}{l}\text { Interest in } \\
\text { politics }\end{array}$ & & & $\begin{array}{r}0.510^{* * * *} \\
(0.032)\end{array}$ & $\begin{array}{r}0.391^{* * *} \\
(0.035)\end{array}$ & $\begin{array}{r}0.504^{* * *} \\
(0.033)\end{array}$ & $\begin{array}{r}0.390^{* * *} \\
(0.036)\end{array}$ \\
\hline Constant & $\begin{array}{r}-1.097^{* * *} \\
(0.154)\end{array}$ & $\begin{array}{r}-2.676^{* * *} \\
(0.189)\end{array}$ & $\begin{array}{r}-1.828^{* * *} \\
(0.137)\end{array}$ & $\begin{array}{r}-3.370^{* * *} \\
(0.191)\end{array}$ & $\begin{array}{r}-1.633^{* * *} \\
(0.151)\end{array}$ & $\begin{array}{r}-3.011^{* * * *} \\
(0.207)\end{array}$ \\
\hline $\mathrm{N}$ & 14,085 & 9,273 & 14,116 & 8,979 & 14,052 & 8,959 \\
\hline $\mathrm{R}^{2}$ & 0.137 & 0.097 & 0.152 & 0.110 & 0.152 & 0.112 \\
\hline
\end{tabular}

Models controlled for country (not reported). ${ }^{*} p<0.05,{ }^{* *} p<0.01,{ }^{* * *} p<0.005$. Standard errors in parentheses.

Control variables have shown that higher education increases the likelihood for protesting very clearly, higher age reduces the likelihood for protesting almost as clearly, and males are obviously more active protesters than females. Results also indicate that those living in urban areas are generally more likely to protest. Although not reported, the country has been a control variable in all models where more than one country is analysed, and in every one of these models, there have been considerable differences between countries.

\subsection{Robustness of results}

In addition to the results presented above a third data set, the second wave of the Arab Barometer (ABII), has been used to test the hypotheses. I have also tested some changes and alternative operationalisations in the models. I tested operationalising employment status with just a single variable which included the unemployed (coded as 1) and the employed (0) but excluded respondents with any other employment status. I tested interaction terms to study the young unemployed and the educated unemployed in hypotheses 2 and 3. In the models with interaction terms, I operationalised employment status using this single variable which only compares the employed and the unemployed and excludes all others. I then multiplied this binary variable with education variable or age variable. I tested having 25 years as the upper limit for youth instead of 35 years used above in hypothesis 2 . I tested including the part-time employed in the analyses in addition to the full-time employed and using voting as a measure for interest in politics instead of direct questions about political interest. 
Further, I tried adding marital status, the number of children, ethnic group, and religion as control variables to analyses modelling protest attendance. All these tested control variables were practically nowhere statistically significant, and adding them did not increase noteworthily the coefficients of determination nor change the seeming impact of employment status. I have also run all the models presented in the article in the subsamples introduced in Table 3.

Thus, in addition to those 25 separate regression analyses presented in Table 2-Table 6, the supplementary material provides the results of altogether 314 regression analyses. The notions of the following chapters are based on these supplementary analyses which are available as Supplementary material, which can be accessed through the link at the end of the article.

In ABII, for Tunisia and for Egypt there are questions (EG802, EG812, T902, and T912) asking whether the respondents participated in the Arab Spring protests prior to and after Ben Ali and Mubarak relinquished their power. In other countries, respondents are asked whether they during the past 3 years had participated "in a protest, march or sit-in" (Q502.2).

To a great extent, results from the supplementary analyses detailed above - alternative operationalisations, the ABII data set, and the aforementioned subsamples - are consistent with the results presented in the article. Thus, the outcomes of all seven hypotheses can be considered robust.

Earlier I recognised that special attention must be given to how to measure unemployment status validly. Three different operationalisations used, one based on the direct question of employment status and two using income as a proxy for employment, all show parallelly that the unemployed are not more active protesters than the employed. Arguably, the three ways of operationalising unemployment provide enough evidence to dispel the concerns about flawed validity.

All these different data sets and different operationalisations provided scant support for the assumption of the unemployed as active protesters. It seems that compared to the employed, the unemployed did not generally take to the streets more often in the Arab Spring uprisings or in other occasions in the studied Arab countries. Mostly there are no clear differences between these two groups, and if there are differences, the evidence suggests that the unemployed are rather less active protesters than the employed.

Interaction effects of employment status and other socio-economic and demographic features have not been the focus of this article. The analyses carried out here do not rule out interaction effects. Still, if the young unemployed or the highly educated unemployed had mobilised especially actively and widespreadly, it should have become more visible in these tests.

The notion of the remote influence of unemployment becomes highlighted if unemployment is compared with the control variables. Education, age, urban residence, and gender have all proved to be relatively strong and statistically significant predictors of protest participation in almost every model and sample. The effect of unemployment is, indeed, slender and controversial. Even if hypothesis 2 provided slightly more hint of the assumed relationship between unemployment and participation in unrests than hypotheses 1 and 3, education and gender were considerably more powerful predictors there, as well. The results also show that the same variables have affected the participation of an individual in the Arab Spring revolts and in other protests of the region.

As some Arab Spring protests involved violence and WVS6 in turn asks specifically about peaceful demonstrations, WVS6 and ABIII do not measure exactly the same thing. The data sets however suggest that to a great extent the same individual level traits have driven people to participate in both the Arab Spring protests and peaceful demonstrations. In this paper, we are primarily interested in the Arab Spring so ABIII can be seen as the principal data and the results from WVS6 as strengthening the findings.

Table 3 indicated that there are differences between countries as to how the unemployed engage in protests. I have run the base model (the leftmost model of Table 2) in all individual countries of all three data sets. When combining results from different data sets and different operationalisations, there appear to be certain countries where the unemployed are more active protesters than the employed whereas in most countries there are no such differences, or the unemployed are less active than the employed. As Table 3 already hinted, further analysis supports the idea of Libya as a country where the unemployed are less active protesters than the employed. In Algeria, on the other hand, all three data sets show that the Algerian unemployed are more active protesters than their employed countrymen.

There is an issue with validity in hypotheses $1,2,3,6$, and 7 which can be called time lag. In ABIII respondents are in practice asked whether they took part in the Arab Spring uprisings up to three and a half years ago, and in WVS6 whether they protested during the preceding year. In ABII respondents in Tunisia and Egypt were asked whether they participated in the Arab Spring uprisings which at the time of the survey had begun 6-10 months earlier. So, in practice, I have modelled the impact of the respondents' employment status and other socio-economic characteristics at the time of the survey on the respondents' protest participation even years earlier. During 6 months or 1 year, there are obviously less changes in employment status and other features compared to changes during several years. Consequently, if time lag would considerably disturb the 
analyses, there should be more support for hypotheses from data where the time between the protests and the survey is shorter. This is not the case. Further, the above-mentioned differences between countries in protest participation of the unemployed indicate a minor effect of time lag.

As noted earlier, in hypotheses 4 and 5 it is debatable to what extent using Likert scale variables and nonnormally distributed explained variables reduces the accuracy of the analyses. However, concerning both time lag and the above-mentioned considerations in linear regression, the slight inaccuracies they caused should not be considered to invalidate results which are as robust and concordant as these.

Throughout all my models the coefficients of determination remain low. This is expected as protesting, satisfaction with life, and interest in politics are phenomena influenced by a lot of contingency. The explanatory power of the regression analyses does not lie in any single model or its coefficient of determination but instead in the abundance of survey data, in the number of the models, and the highly similar results they indicate.

\subsection{Comparisons with earlier research}

The results of all hypotheses are summarised in Figure 4.

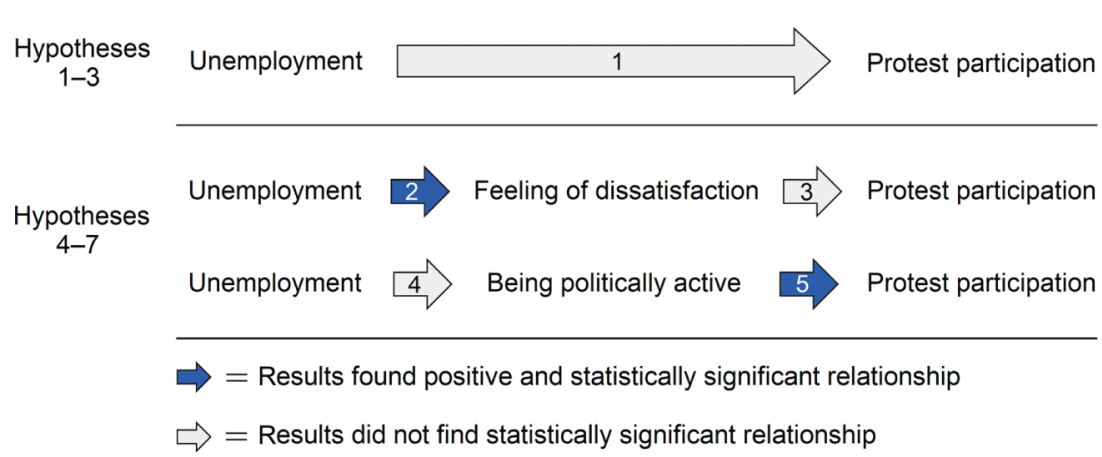

Figure 4: Findings of the hypotheses.

The arrows in the figure indicate assumed relationships, and the colours of the arrows tell whether the results suggested a positive relationship (blue) or no relationship at all (blank). None of the relationships presented in the figure was predominantly negative. The figure partly generalises the results but in short, my analyses show that the likelihood of the unemployed of taking to the streets is not higher (arrow 1) despite the fact that they are more dissatisfied (arrow 2). Further, this passivity of the unemployed can be partly explained with the finding that, in general, dissatisfaction with life does not increase the likelihood of protesting (arrow 3). Being interested in politics then again increases the likelihood of protesting (arrow 4). But the unemployed are rather less interested in politics (arrow 5), and my results hint that this lessens their participation in protests.

On the other hand, one should not make too bold claims about causality on the basis of this article. For example, it might be that individual-level personality traits, such as being enterprising or sociable person, make people both politically active and employed. It seems more plausible to think that interest in politics drives people to participate in protests than the other way around, i.e. that participating in protests would make people interested in politics. On the other hand, while being unemployed can arguably make people dissatisfied with life, being dissatisfied might also make it harder to get a job. But even we cannot be sure about causalities between the different factors, this does not change the core results that the unemployed are unhappy but relatively passive protesters compared to the employed. After all, it perhaps seems understandable that the unemployed were less eager to take part in the Arab Spring protests. Maybe people who have problems in feeding themselves are not so interested in whether the country is governed democratically or not.

Earlier literature has emphasised the important role labour unions often play in the mobilisation of the unemployed and the differences between countries in how labour unions take the jobless into consideration (Chabanet \& Faniel, 2011, pp. 398-404; Klandermans, 2011, p. 45). This might offer one explanation for the suggestive result that the unemployed were more passive in some Arab countries than in others. Langhor (2014) has found that countries differed considerably as to which role the labour unions took in the Arab Spring uprisings.

Until now we have traced the relationship between unemployment and political instability by observing whether the unemployed have been active rebels compared to the employed. But people who are not unemployed themselves can take political action concerning unemployment (Schlozman \& Verba, 1979, p. 20). This can happen because of solidarity or because of a large number of unemployed makes those who are working concerned about their own future. The employed and unemployed are connected through social networks. They can also live in the same households. 
In Tunisia the most chanted slogan of the Arab Spring protesters is said to have been "Employment, freedom, and dignity" (Ben Mhenni, 2014). Soon after the uprising had toppled Tunisia's former ruler Ben Ali, a survey found that $60 \%$ regarded unemployment as the biggest or second biggest problem facing the country (International Republican Institute, 2011). Thus, it seems that people brought out their frustration with unemployment, even though in Tunisia the unemployment rate had rather steadily decreased during the decades before the Arab Spring (World Bank, 2019). Arampatzi, Burger, Ianchovichina, Röhricht, and Veenhoven (2018) have demonstrated that as a whole there were substantial improvements in economic and social indicators throughout the Middle East and North Africa region during the decades preceding the Arab Spring. But simultaneously, in the years before the Arab Spring people had become increasingly less satisfied with their lives. Arampatzi et al. identify this as the "unhappy development" paradox.

We know now that the unemployed were not more likely to revolt and that in most Arab countries the unemployment rates decreased or remained steady in the decade preceding the Arab Spring (World Bank, 2019). It also seems that people can be dissatisfied with the employment situation even if the unemployment rate has decreased. People who are not unemployed themselves might riot because of unemployment. But on the other hand, those who are less satisfied are not more likely to protest. The results of this study should not be interpreted as a proof that unemployment was irrelevant for the Arab Spring. Still, the results give us a strong reason to question whether unemployment was as important a factor in this chain of events as many have suggested.

\section{Conclusion}

It is important to study the significance of unemployment for political instability to get a better understanding of the mechanisms behind rebellions, but also to provide guidance for policies aiming at preventing political instability.

This study found that compared to the employed, the unemployed generally were no more likely to participate in the Arab Spring uprisings or some other protests of the region. This outcome is robust and all three different ways used to operationalise unemployment support it. Unlike what was hypothesised, in several cases it turned out that the unemployed actually are less likely to protest than the employed. The results suggest that, due to their low interest in politics, the dissatisfaction of the unemployed probably does not erupt as rioting. Theoretical considerations also provide other possible explanations for why the unemployed do not take action. This might be due to the fact that they, for example, lack social networks, are marginalised or believe that rebelling is unlikely to bring them jobs. Taken together, although my results do not provide a complete picture, all the results of the study form a logical whole, where one part supports the other.

The results show clearly and consistently that being younger and being more educated are, as expected, factors which increase the likelihood of an individual to protest. This finding further underlines the slight and controversial effect of being unemployed.

Earlier research studying other countries indicates that unemployment is not a strong causal factor predicting political instability at an individual or country or region level. The key result of this study is in line with this finding; neither does unemployment seem to have been a major driving force behind the Arab Spring. Against the background of earlier research this result might seem expected, but taken into account the numerous assumptions about the linkage of the Arab Spring and unemployment, these findings are rather surprising.

There are - as far as I know - no prior studies which would have focused on the role of the unemployed in the revolts of the Arab Spring. So first, this study has shed more light on the net of drivers behind the Arab Spring. Second, this study is novel in the thoroughness with which it examines the role of unemployment in the protests of the Arab countries more generally. But in addition, neither has the significance of unemployment for protest movements and rebellions globally been studied too much. This study is one new case study to increase our knowledge in this field.

It is not advisable to make, based on these results, country-specific assumptions about the passivity or activity of the unemployed elsewhere. One indicative result of this study is that there are considerable differences between countries in how unemployment influences the protest engagement of individuals. Thus one direction for future research would be to explore whether the differences really are country specific. And if countryspecific differences do exist, could they at least partly explain contradictory results of earlier research in relation to unemployment and political instability? And further, what causes these differences between countries in the first place?

On the other hand, something from all this could be generalised. Namely, based on both my results and earlier studies, the significance of unemployment as a driver of political instability generally appears to be weaker and more complex than is often assumed. As to policy recommendations, this study joins those previous 
analyses which suggest that programmes aiming at fostering peace solely through creating jobs are likely to miss their target.

\section{Acknowledgements}

I wish to thank Halvard Buhaug, Markku Löytönen, Maria Mekri, Henrik Urdal, and various seminar audiences for helpful advices and comments in different phases of the work. I am grateful to the Editor in Chief Raul Caruso and the anonymous reviewer for thorough and valuable feedback.

\section{Funding}

The article has been finalised during my work in the project What works? Youth transitions from education to employment in the Middle East and North Africa funded by the Academy of Finland, Funder Id: http:/ /dx.doi.org/10.13039/501100002341, decision no 320449.

\section{Appendix A}

Table 7: Descriptive statistics of ABIII.

\begin{tabular}{|c|c|c|c|c|c|}
\hline & $\mathbf{N}$ & Minimum & Maximum & Mean & Std. Deviation \\
\hline $\begin{array}{l}\text { Employment status: unemployed }^{\dagger} \\
\text { (unemployed }=1 ; \text { Employed = } 0 \text { ) }\end{array}$ & 6,286 & 0 & 1 & 0.28 & 0.449 \\
\hline $\begin{array}{l}\text { Employment status: employed (employed }=1 \text {; } \\
\text { unemployed \& others }=0 \text { ) }\end{array}$ & 14,729 & 0 & 1 & 0.31 & 0.461 \\
\hline $\begin{array}{l}\text { Employment status: others (others }=1 \\
\text { employed \& unemployed }=0 \text { ) }\end{array}$ & 14,729 & 0 & 1 & 0.57 & 0.495 \\
\hline High income (absolute) & 9,974 & 1 & 10 & 5.01 & 3.083 \\
\hline High income (relative) & 14,417 & 1 & 4 & 2.27 & 0.948 \\
\hline Urban residence & 14,648 & 0 & 1 & 0.67 & 0.470 \\
\hline Male & 14,809 & 0 & 1 & 0.50 & 0.500 \\
\hline Age & 14,799 & 18 & 89 & 37.80 & 13.886 \\
\hline High education & 14,775 & 1 & 4 & 2.63 & 1.042 \\
\hline Married & 14,795 & 0 & 1 & 0.64 & 0.481 \\
\hline Protest participation & 14,427 & 0 & 1 & 0.14 & 0.345 \\
\hline Satisfied with life & 14,649 & 1 & 5 & 2.96 & 0.805 \\
\hline Interest in politics & 14,662 & 1.0 & 4.0 & 2.42 & 0.921 \\
\hline
\end{tabular}

${ }^{+}$This variable has not been used in the regression analyses reported in the article, it is here to illustrate correlations between unemployment and other variables. Other respondents than the unemployed and the employed are excluded in this variable.

Table 8: Descriptive statistics of WVS6.

\begin{tabular}{|c|c|c|c|c|c|}
\hline & $\mathbf{N}$ & Minimum & Maximum & Mean & Std. Deviation \\
\hline $\begin{array}{l}\text { Employment status: unemployed }^{+} \\
\text {(unemployed }=1 \text {; employed }=0 \text { ) }\end{array}$ & 3,172 & 0 & 1 & 0.28 & 0.447 \\
\hline $\begin{array}{l}\text { Employment status: employed (employed }=1 \text {; } \\
\text { unemployed \& others }=0 \text { ) }\end{array}$ & 10,307 & 0 & 1 & 0.22 & 0.416 \\
\hline $\begin{array}{l}\text { Employment status: others (others }=1 \\
\text { employed \& unemployed }=0 \text { ) }\end{array}$ & 10,307 & 0 & 1 & 0.69 & 0.462 \\
\hline High income (absolute) & 10,021 & 1 & 10 & 4.89 & 2.150 \\
\hline Urban residence & 10,101 & 0 & 1 & 0.57 & 0.496 \\
\hline Male & 10,336 & 0 & 1 & 0.51 & 0.500 \\
\hline Age & 10,336 & 18 & 90 & 37.93 & 14.439 \\
\hline High education & 10,296 & 1 & 4 & 2.62 & 1.033 \\
\hline Married & 10,334 & 0 & 1 & 0.60 & 0.491 \\
\hline
\end{tabular}




\begin{tabular}{|c|c|c|c|c|c|}
\hline Protest participation & 9,595 & 0 & 1 & 0.15 & 0.359 \\
\hline Satisfied with life & 10,218 & 1 & 10 & 6.35 & 2.481 \\
\hline Interest in politics & 9,796 & 1.0 & 4.0 & 2.31 & 0.948 \\
\hline
\end{tabular}

${ }^{\dagger}$ This variable has not been used in the regression analyses reported in the article, it is here to illustrate correlations between unemployment and other variables. Other respondents than the unemployed and the employed are excluded in this variable.

\begin{tabular}{|c|c|c|c|}
\hline \multirow[t]{2}{*}{$\begin{array}{l}\text { Variable: } \\
\text { Questions: }\end{array}$} & \multicolumn{3}{|c|}{$\begin{array}{l}\text { Are you? (q1005) } \\
\text { Do you work full time or part time? (q1006) }\end{array}$} \\
\hline & & Frequency & Percent \\
\hline \multirow[t]{8}{*}{ Valid } & Employed, full-time & 4,529 & 30.6 \\
\hline & Employed, part-time & 2,069 & 14.0 \\
\hline & Retired & 843 & 5.7 \\
\hline & Housewife & 4,133 & 27.9 \\
\hline & Student & 1,317 & 8.9 \\
\hline & Unemployed & 1,757 & 11.9 \\
\hline & Other & 81 & 0.5 \\
\hline & Total & 14,729 & 99.5 \\
\hline Missing & & 80 & 0.5 \\
\hline Total & & 14,809 & 100.0 \\
\hline
\end{tabular}

\begin{tabular}{|c|c|c|c|}
\hline \multirow[t]{2}{*}{$\begin{array}{l}\text { Variable: } \\
\text { Question: }\end{array}$} & \multicolumn{3}{|c|}{$\begin{array}{l}\text { The Arab Spring led some } \\
\text { demonstrations and rallies in (country } \\
\text { name). Did you participate in any of } \\
\text { these events? (in } 2011 \text { and 2012) ( }(9800 \text { a) }\end{array}$} \\
\hline & & Frequency & Percent \\
\hline \multirow[t]{3}{*}{ Valid } & No, I did not & 12,429 & 83.9 \\
\hline & Yes, I did & 1,998 & 13.5 \\
\hline & Total & 14,427 & 97.4 \\
\hline Missing & & 382 & 2.6 \\
\hline Total & & 14,809 & 100.0 \\
\hline
\end{tabular}

World Values Survey 6

\begin{tabular}{|c|c|c|c|}
\hline \multicolumn{4}{|c|}{ World Values Survey 6} \\
\hline Variable: & \multicolumn{3}{|l|}{ Employment status } \\
\hline & & Frequency & Percent \\
\hline \multirow[t]{9}{*}{ Valid } & Employed, full-time & 2,299 & 22.2 \\
\hline & Employed, part-time & 1,189 & 11.5 \\
\hline & Self employed & 1,462 & 14.1 \\
\hline & Retired & 613 & 5.9 \\
\hline & Housewife & 2,583 & 25.0 \\
\hline & Students & 1,185 & 11.5 \\
\hline & Unemployed & 873 & 8.4 \\
\hline & Other & 103 & 1.0 \\
\hline & Total & 10,307 & 99.7 \\
\hline Missing & & 29 & 0.3 \\
\hline Total & & 10,336 & 100.0 \\
\hline Variable: & \multicolumn{3}{|c|}{ Protest participation } \\
\hline Questions: & \multicolumn{3}{|c|}{$\begin{array}{l}\text { I'm going to read out some forms of political } \\
\text { action that people can take, and I'd like you to } \\
\text { tell me, for each one, whether you have done any } \\
\text { of these things, whether you might do it or would } \\
\text { never under any circumstances do it: Attending } \\
\text { peaceful demonstrations (v87) }\end{array}$} \\
\hline & \multicolumn{3}{|c|}{$\begin{array}{l}\text { Tell me for each of these activities how often } \\
\text { you have done it in the last year (Only to those } \\
\text { who said they "have done" the given protest } \\
\text { activity): Attending peaceful demonstrations } \\
\text { (v92) }\end{array}$} \\
\hline \multirow[t]{2}{*}{ Note: } & \multicolumn{3}{|c|}{$\begin{array}{l}\text { Options "Might do" and "Would never do" in } \\
\text { v8 } 7 \text { are combined as "Have not done". Those } \\
\text { who have attended demonstration but not in the } \\
\text { last year are counted as "Have not done". }\end{array}$} \\
\hline & & Frequency & Percent \\
\hline \multirow[t]{3}{*}{ Valid } & Have not done & 8,138 & 78.7 \\
\hline & Have done & 1,457 & 14.1 \\
\hline & Total & 9,595 & 92.8 \\
\hline Missing & & 741 & 7.2 \\
\hline Total & & 10,336 & 100.0 \\
\hline
\end{tabular}




\begin{tabular}{|c|c|c|c|}
\hline \multirow[t]{2}{*}{$\begin{array}{l}\text { Variable: } \\
\text { Question: }\end{array}$} & \multicolumn{3}{|c|}{$\begin{array}{l}\text { Satisfied with life } \\
\text { Generally speaking, how would you } \\
\text { compare your living conditions with the } \\
\text { rest of your fellow citizens? (q102a) }\end{array}$} \\
\hline & & Frequency & Percent \\
\hline \multirow[t]{6}{*}{ Valid } & Much worse & 757 & 5.1 \\
\hline & Worse & 2,391 & 16.1 \\
\hline & Similar & 8,586 & 58.0 \\
\hline & Better & 2,520 & 17.0 \\
\hline & Much better & 395 & 2.7 \\
\hline & Total & 14,649 & 98.9 \\
\hline Missing & & 160 & 1.1 \\
\hline Total & & 14,809 & 100.0 \\
\hline
\end{tabular}

Variable: Interest in politics

Questions: In general, to what extent are yo interested in politics? (q404) To what extent do you follow political news in your country? (q405)

Note: In both questions respondents rate their interest in a four-step scale. I have inverted the scales so that higher value indicates higher values.

\begin{tabular}{llrr}
\hline & & Frequency & Percent \\
\hline Valid & 1.0, Not interested & 2,071 & 14.0 \\
& 1.5 & 1,509 & 10.2 \\
& 2.0 & 3,259 & 22.0 \\
& 2.5 & 2,056 & 13.9 \\
& 3.0 & 3,005 & 20.3 \\
& 3.5 & 1,133 & 7.7 \\
& 4.0, Very interested & 1,629 & 11.0 \\
& Total & 14,662 & 99.0 \\
\hline Missing & & 147 & 1.0 \\
\hline Total & & 14,809 & 100.0
\end{tabular}

Figure 5: Frequency tables of the main variables.
Variable: Satisfied with life

Question: All things considered, how satisfied are you with your life as a whole these days? (v23)

\begin{tabular}{llrr}
\hline & Frequency & Percent \\
\hline Valid & 1, Completely dissatisfied & 522 & 5.1 \\
& 2 & 290 & 2.8 \\
& 3 & 575 & 5.6 \\
& 4 & 629 & 6.1 \\
& 5 & 1,898 & 18.4 \\
& 6 & 1,243 & 12.0 \\
& 7 & 1,572 & 15.2 \\
& 8 & 1,305 & 12.6 \\
& 9 & 698 & 6.8 \\
& 10, Completely satisfied & 1,486 & 14.4 \\
\cline { 2 - 4 } & Total & 10,218 & 98.9 \\
\hline Missing & & 118 & 1.1 \\
\hline Total & & 10,336 & 100.0 \\
\hline
\end{tabular}

Variable: Interest in politics

Questions: How interested would you say you are in politics? (v84) For each of the following, indicate how important it is in your life: Politics (v7)

Note: In both questions respondents rate their interest in a four-step scale. I have inverted the scales so in a four-step scale. Thave inverted the scales so
that higher value indicates higher interest and calculated the average of these values.

\begin{tabular}{llrr} 
& & Frequency & Percent \\
\hline Valid & 1.0, Not important / & 1,963 & 19.0 \\
& Not interested & 1,119 & 10.8 \\
& 1.5 & 1,750 & 16.9 \\
& 2.0 & 1,370 & 13.3 \\
& 2.5 & 1,879 & 18.2 \\
& 3.0 & 906 & 8.8 \\
& 3.5 & 809 & 7.8 \\
& 4.0. Very important / & & \\
& Very interested & 9,796 & 94.8 \\
\cline { 2 - 4 } & Total & 540 & 5.2 \\
\hline Missing & & 10,336 & 100.0 \\
\hline Total & & & \\
\hline
\end{tabular}

\section{Appendix B}




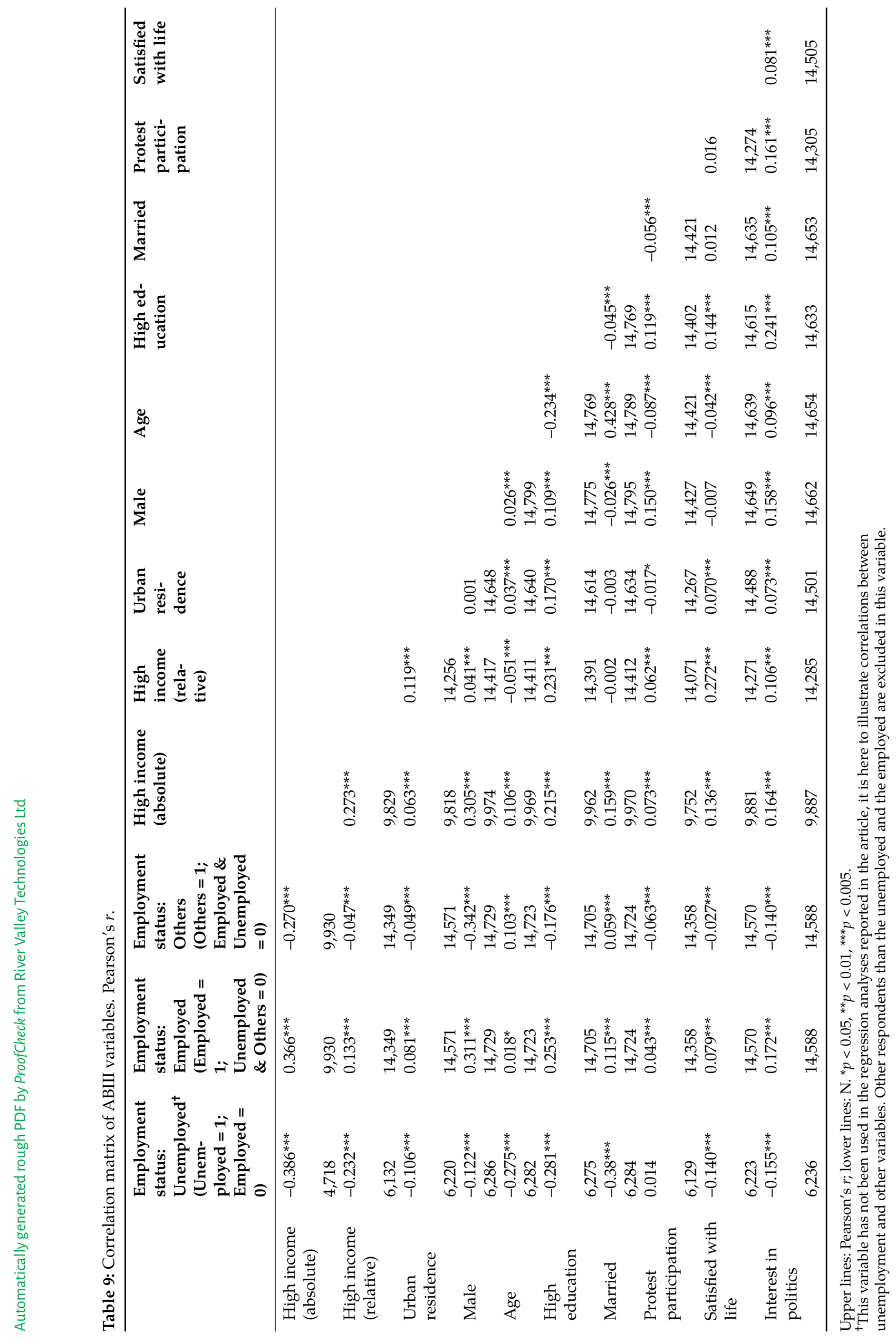




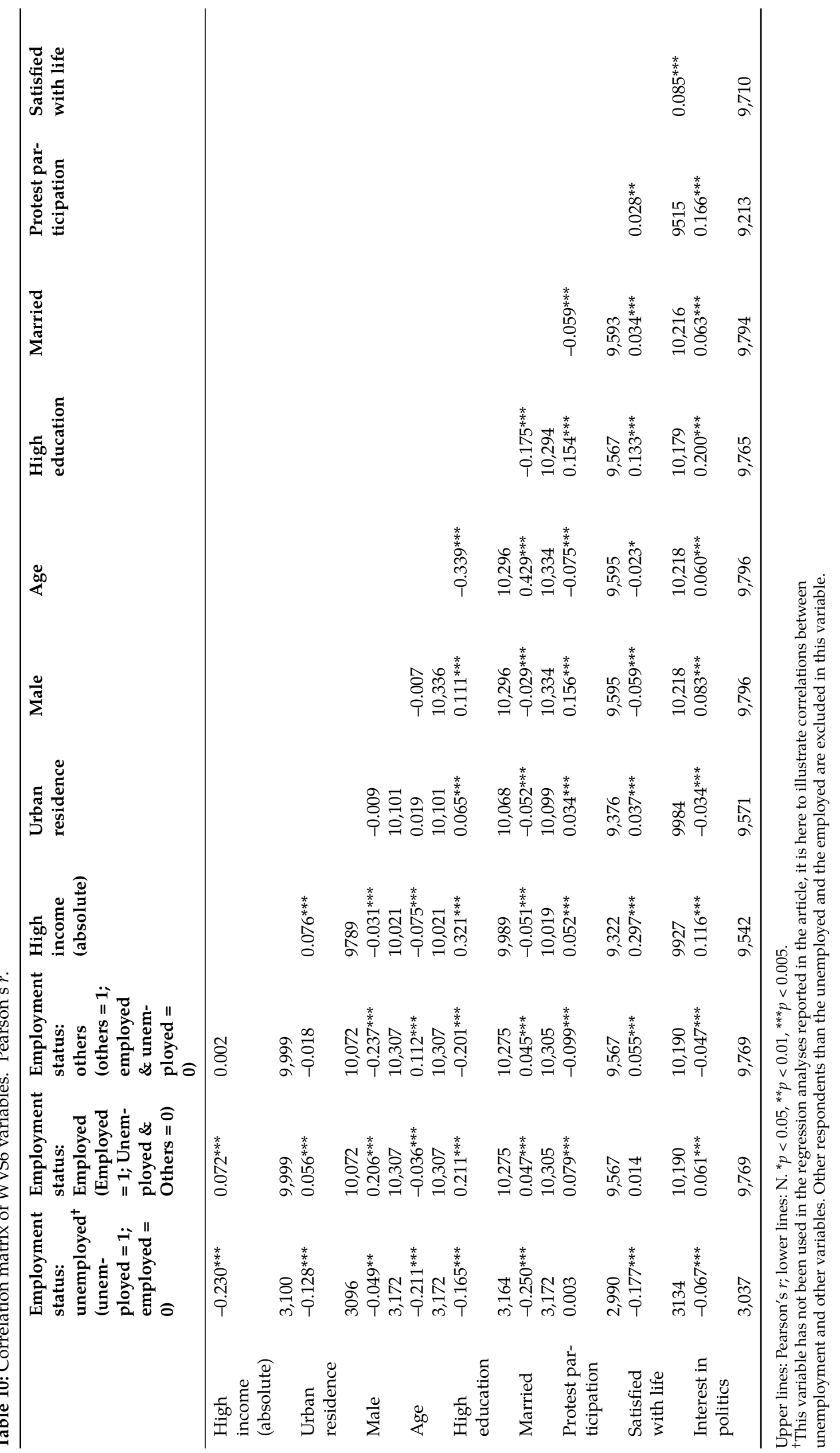




\section{References}

Allansson, M., Baumann, J., Taub, S., Themnér, L., \& Wallensteen, P. (2012). The first year of the Arab Spring. In Stockholm international peace research institute, SIPRI yearbook 2012: Armaments, disarmament and international security (pp. 45-56). Oxford: Oxford University Press.

Anderson, L. (2011). Demystifying the Arab Spring: Parsing the differences between Tunisia, Egypt, and Libya. Foreign Affairs, 90(3), 2-7.

Arampatzi, E., Burger, M., lanchovichina, E., Röhricht, T., \& Veenhoven, R. (2018). Unhappy development: Dissatisfaction with life on the eve of the Arab Spring. Review of Income and Wealth, 64(1), S80-S113

Azeng, T. F., \& Yogo, T. U. (2013). Youth unemployment and political instability in selected developing countries. African Development Bank, Working Paper Series 171

Baglioni, S., Baumgarten, B., Chabanet, D., \& Lahusen, C. (2010). Transcending marginalization: The mobilization of the unemployed in France, Germany, and Italy in a comparative perspective. In M. Giugni (Ed.), The contentious politics of unemployment in Europe: Welfare states and political opportunities (pp. 152-168). New York: Palgrave Macmillan.

Becker, C. (1968). Crime and punishment: An economic approach. Journal of Political Economy, 76(2), 169-217.

Beissinger, M. R., Jamal, A., \& Mazur, K. (2012). Who participated in the Arab Spring? A comparison of Egyptian and Tunisian revolutions. Working paper, Princeton University.

Ben Mhenni, L. (2014). Opinion: Tunisia's leaders have failed the dignity revolution. CNN 22.1.2014. <http://edition.cnn.com/2014/01/22/business/davos-tunisia-dignity-revolution-ben-mhenni/index.html>, accessed 8.2.2019.

Berman, E., Callen, M., Felter, J. H., \& Shapiro, J. N. (2011). Do working men rebel? Insurgency and unemployment in Afghanistan, Iraq, and the Philippines. Journal of Conflict Resolution, 55(4), 496-528.

Bjorvatn, K., \& Høigilt, ]. (2016). Youth and the Arab revolutions. In K. Selvik \& B. O. Utvik (Eds.), Oil states in the new Middle East: Uprisings and stability (pp. 39-56). Abingdon, Oxon: Routledge.

Botha, A., \& Abdile, M. (2014). Radicalisation and al-Shabaab recruitment in Somalia. Institute for security Studies, Paper 266.

Buhaug, H., Cederman, L.-E., \& Gleditsch, K. S. (2014). Square pegs in round holes: Inequalities, grievances, and civil war. International Studies Quarterly, 58(2), 418-431.

Byun, C. C., \& Hollander, E. J. (2015). Explaining the intensity of the Arab Spring. Digest of Middle East Studies, 24(1), 26-46.

Campante, F. R., \& Chor, D. (2012). Why was the Arab world poised for revolution? Schooling, economic opportunities, and the Arab Spring. Journal of Economic Perspectives, 26(2), 167-188.

Chaaban, J. (2010). Job creation in the Arab economies: Navigating through difficult waters. Arab Human Development Report, Research Paper Series.

Chabanet, D., \& Faniel, J. (2011). The mobilization of the unemployed: A recurrent but relatively invisible phenomenon. In M. Reiss \& M. Perry (Eds.), Unemployment and protest: New perspectives on two centuries of contention (pp. 387-405). Oxford: Oxford University Press.

Collier, P., \& Hoeffler, A. (1998). On economic causes of civil war. Oxford economic papers, 50(4), 563-573.

Cramer, C. (2011). Unemployment and participation in violence. World Development Report 2011 Background Paper.

Creutz, K. (2015). Osahanke 2. In K. Creuz, J. Saarinen, \& M. Juntunen (Eds.): Syrjintä, polarisaatio, nuoriso ja väkivaltainen radikalisoituminenSYNOPUR-väliraportti (pp. 10-47). SSKH Reports and Discussion Papers 5/2015.

Doherty, D., \& Schraeder, P. J. (2015). Patterns of participation in a revolution and its aftermath. Working paper, Loyola University Chicago.

Gelvin, J. L. (2012). The Arab uprisings: What everyone needs to know. Oxford: Oxford University Press.

Giugni, M. (2008). Welfare states, political opportunities, and the mobilization of the unemployed: A cross-national analysis. Mobilization: An International Journal, 13(3), 297-310.

Coldstone, J. A. (2011). Understanding the revolutions of 2011: Weakness and resilience in Middle Eastern autocracies. Foreign Affairs, 90(3), 8-16.

Grossman, H. (1991). A general equilibrium model of insurrections. American Economic Review, 81, 912-921.

Curr, T. R. (1970). Why men rebel. Princeton, N]: Princeton University Press.

Gutierréz-Sanín, F. (2008). Telling the difference: Cuerrillas and paramilitaries in the Colombian war. Politics Society, 36(3), 3-34.

Hoffman, M., \& Jamal, A. (2012). The youth and the Arab Spring: Cohort differences and similarities. Middle East Law and Covernance, 4(1), 168-188.

Hoffman, M., \& Jamal, A. (2014). Religion in the Arab Spring: Between two competing narratives. The Journal of Politics, 76(3), 593-606.

Holmes, R., McCord, A., Hagen-Zanker, ]., Bergh, G., \& Zanker, F. (2013). What is the evidence of the impact of employment creation on stability and poverty reduction in fragile states? A systematic review. London: Overseas Development Institute. $<$ http://rud.dfid.gov.uk/pdf/outputs/systematicreviews/What_is_the_evidence_on_the_impact_of_employment_creation_on_stability_ and_poverty_reduction_in_fragile_states.pdf>, accessed 8.2.2019.

Honaker, J. (2010). Unemployment and violence in Northern Ireland: A missing data model for ecological inference. Paper presented to the Quantitative Social Science Initiative (QuaSSI) at the Pennsylvania State University, February 2010.

International Labour Organization. (2011). Youth unemployment in the Arab world is a major cause for rebellion. 5.4.2011. <http://www.ilo.org/global/about-the-ilo/newsroom/features/WCMS_154078/lang-en/index.htm>, accessed 8.2.2019.

International Republican Institute. (2011). Survey of Tunisian public opinion. $<$ http://www.iri.org/sites/default/files/2011\%20April\%2010\% 20Survey\%20of\%20Tunisian\%20Public\%20Opinion\%20March\%205-18\%202011\%20FINAL.pdf>, accessed 8.2.2019.

Jahoda, M., Lazarsfeld, P. F., Zeisel, H., \& Fleck, C. (1933/2002). Marienthal: The sociography of an unemployed community, orig. Die Arbeitslosen von Marienthal. New Brunswic (New Jersey): Transaction Publishers.

Klandermans, B. (2011). Mobilizing the unemployed: The social psychology of movement participation. In M. Reiss \& M. Perry (Eds.), Unemployment and protest: New perspectives on two centuries of contention (pp. 39-56). Oxford: Oxford University Press.

Lahusen, C. (2013). The protests of the unemployed in France, Germany and Sweden (1994-2004): protest dynamics and political contexts. Social Movement Studies, 12(1), 1-22. 
Langhor, V. (2014). Labor movements and organizations. In M. Lynch (Ed.), The Arab uprisings explained: New contentious politics in the Middle East (pp. 180-200). New York: Columbia University Press.

Lichbach, M. I. (1995). The rebel's dilemma. Ann Arbor: University of Michigan Press.

Long, S. J., Long, J. S., \& Freese, ]. (2006). Regression models for categorical dependent variables using Stata. College Station: Stata Press.

Lumley, T., Diehr, P., Emerson, S., \& Chen, L. (2002). The importance of the normality assumption in large public health data sets. Annual Review of Public Health, 23(1), 151-169.

Malik, A., \& Awadallah, B. (2013). The economics of the Arab Spring. World Development, 45, $296-313$.

Mirkin, B. (2013). Arab human development report: Arab Spring demographics in a region in transition. Arab Human Development Report, Research Paper Series.

Newsom, J. T. (2013). Levels of measurement and choosing the correct statistical test. Data Analysis I, Handouts for topics on hypothesis testing to ANOVA. <http://web.pdx.edu/ newsomj/da1/ho_levels.pdf>, accessed 11.5.2018.

Olzak, S., \& Shanahan, S. (1996). Deprivation and race riots: An extension of Spilerman's analysis. Social Forces, 74(3), 931-961.

Olzak, S., Shanahan, S., \& McEneaney, E. H. (1996). Poverty, segregation, and race riots: 1960 to 1993. American Sociological Review, 61(4), 590613.

Ottaway, M., \& Hamzawy, A. (2011). Protest movements and political change in the Arab world. Carnegie Endowment for International Peace, Policy Outlook January 28.

Oyefusi, A. (2010). Oil, youths, and civil unrest in Nigeria's delta: The role of schooling, educational attainments, earnings, and unemployment. Conflict Management and Peace Science, 27(4), 326-346.

Perry, M., \& Reiss, M. (2011). Beyond Marienthal. In M. Reiss \& M. Perry (Eds.), Unemployment and protest: New perspectives on two centuries of contention (pp. 3-37). Oxford: Oxford University Press.

Proctor, K. (2015). Youth \& consequences: Unemployment, injustice and violence. Portland, Oregon: Mercy Corps.

Reiss, M., \& Perry, M. (2011). Unemployment and protest: New perspectives on two centuries of contention. Oxford: Oxford University Press.

Robbins, M. D. (2014). Re: Questions about the Arab Barometer data. Personal email from<mdr7@princeton.edu>, 23.7.2014.

Sadiki, L. (2000). Popular uprisings and Arab democratization. International Journal of Middle East Studies, 32(1), 71-95.

Scacco, A. (2007). Individual participation in violent demonstrations in Nigeria. Working Paper, Columbia University.

Schlozman, K. L., \& Verba, S. (1979). Injury to insult: Unemployment, class, and political response. Cambridge (Massachusetts): Harvard University Press.

Shafiq, M. N., \& Vignoles, A. (2015). Beyond the Arab Spring: Education, earnings, and protest participation. Paper prepared for the AALIMSPrinceton Conference on Islam and Human Capital, October 2015

The Guardian. (2011). Young Arabs who can't wait to throw off shackles of tradition. 14.2.2011. <https://www.theguardian.com/world/2011/feb/14/young-arabs-throw-off-shackles-tradition>, accessed 8.2.2019.

Thompson, J. L. P. (1989). Deprivation and political violence in Northern Ireland, 1922-85: A time series analysis. The Journal of Conflict Resolution, 33(4), 676-699.

Urdal, H. (2006). A clash of generations? Youth bulges and political violence. International Studies Quarterly, 50(3), 607-629.

Vehkalahti, K. (2008). Kyselytutkimuksen mittaritja menetelmät. Helsinki: Tammi.

White, R. W. (1993). On measuring political violence: Northern Ireland, 1969-1980. American Sociological Review, 58(4), 575-585.

World Bank. (2019). World development indicators data set: Data and Series, updated 24th April, 2019. <http://data.worldbank.org/datacatalog/world-development-indicators>, accessed 14.6.2019.

Supplementary Material: The online version of this article offers supplementary material (DOI: https://doi.org/10.1515/peps-2019-0007). 